\title{
3-4aastaste eesti laste üldoskuste tase kolme hindamisvahendi alusel
}

\author{
Pille Häidkind $^{\text {al }}$, Astra Schults ${ }^{\text {ab }}$, Kaili Palts ${ }^{\mathrm{ac}}$ \\ ${ }^{a}$ Tartu Ülikooli haridusteaduste instituut \\ ${ }^{b}$ Tartu Ülikooli psühholoogia instituut \\ ${ }^{c}$ Haapsalu Neuroloogiline Rehabilitatsioonikeskus
}

\begin{abstract}
Annotatsioon
Eesti lasteaiaõpetajatel on kohustus hinnata igal õppeaastal laste individuaalset arengut ning anda lapsevanematele selle kohta tagasisidet. 3-4aastaste laste üldoskuste tasemele hinnangut andes saavad õpetajad lähtuda koolieelse lasteasutuse õppekavast, milles nad on riiklikele juhendmaterjalidele toetudes ära kirjeldanud laste eakohase arengutaseme. Tõenduspõhist teavet 3-4aastaste eesti laste üldoskuste taseme kohta on aga vähe. Aastatel 2014-2016 Tartu Ülikoolis tehtud rakendusuuringu käigus kogusime andmeid 3-4aastaste eesti laste teadmiste ja oskuste kohta. Andmekogumiseks kasutasime sotsiaalsete oskuste küsimustikku $(N=450)$, Strebeleva metoodikat $(N=262)$ ja PEP-3 testi $(N=127)$. Uuringu tulemusena täpsustus teave 3-4aastaste laste üldoskuste taseme kohta ning sellele tuginedes saab eakohase arengutaseme kirjeldusi koolieelsete lasteasutuste õppekavades sõnastada konkreetsemalt.
\end{abstract}

Võtmesõnad: üldoskused koolieelses eas, sotsiaalsed ja enesekohased oskused, tunnetus- ja õpioskused, mänguoskused, 3-4aastased eesti lapsed

\section{Sissejuhatus}

Areng on terviklik protsess, mille kirjeldamisel võib eristada üksikute ainevaldkondade põhiste teadmiste ja oskuste kujunemist või keskenduda valdkondadeülestele oskustele ehk üldoskustele (Botting \& Marshall, 2017; Knops, Nuerk, \& Göbel, 2017). Koolieelse lasteasutuse riikliku õppekava (2008) neljandas peatükis tuuakse välja 6-7aastase lapse eeldatavad üldoskused neljas valdkonnas: sotsiaalsed oskused, enesekohased oskused, tunnetus- ja õpioskused

Tartu Ülikooli haridusteaduste instituut, Salme 1a, 50103 Tartu; pille.haidkind@ut.ee 
ning mänguoskused. Eesti laste üldoskusi ja õpetajate arusaama üldoskustest on põhjalikumalt uuritud koolieas (Kikas, 2014). Uurimistulemusena leiti, et õpetajatel puudub selge seisukoht, kuidas üldoskusi määratleda, mismoodi neid hinnata ning kuidas nende arengut toetada. Sarnaseid raskusi kogevad ka lasteaiaõpetajad, eriti seoses mänguoskustega, mida peetakse koolieelses eas üldoskuste hulgas kõige olulisemaks valdkonnaks (Neudorf, Ugaste, Tuul, \& Mikser, 2017).

Üldoskuste omandatuse hindamine ja eakohase arengutasemega kõrvutamine ning lapsevanematele selle kohta tagasiside andmine on lasteaiaõpetajate iga-aastane töökohustus. Kui 6-7aastaste laste puhul on riiklikus õppekavas eeldatavad arengutulemused sõnastatud loeteluna, siis nooremates vanuseastmetes tuleb eakohane üldoskuste tase ja selle hindamise meetodid kokku leppida koolieelse lasteasutuse õppekava raames (Koolieelse lasteasutuse riiklik õppekava, 2008). Eesti Vabariigi haridusseaduse (1992) paragrahv 6 alusel on Haridus- ja Teadusministeeriumi üks pädevusi suunata ja korraldada haridusasutuste õppemetoodiliste vahendite koostamist, tagada nende väljaandmine, esitada õppekirjanduse kasutamise soovitusi. Sel eesmärgil on kehtiva koolieelse lasteasutuse riikliku õppekava (2008) rakendamiseks antud välja neli juhendmaterjali, millest ühes kirjeldatakse laste üldoskuste arengut eri vanuseastmetes. Peatükkide autorid on teadlased ja praktikud (Männamaa \& Marats, 2009; Ugaste, Tuul, \& Välk, 2008), kuid puuduvad viited alusuuringutele, mille alusel on eeldatavad arengutulemused sõnastatud.

Eesti lasteaiaõpetajate oskus õppekava koostada on ebaühtlane (Ugaste, Tuul, Mikser, Neudorf, \& Jürimäe, 2016). Seejuures puudub ülevaade, millele tuginedes on koolieelsete lasteasutuste õppekavades kirjeldatud nooremate kui 6-7aastaste laste eakohase arengu taset, samuti sellest, mis üldoskusi peetakse ootuspäraseks. Vanusepõhised orientiirid koolieelse lasteasutuse õppekavas on väga olulised, kuna eeldatavatest arengutulemustest lähtudes eesmärgistab õpetaja terveks aastaks õppe- ja kasvatustegevuse, sh planeerib üldoskuste arengu toetamise ja hindab, kuivõrd eakohane on laste arengutase. Probleemiks on ka óppekava arvestavate usaldusväärsete hindamisvahendite puudus. Näiteks on Must (2014) õpetajaid küsitledes leidnud, et õpetajad hindavad lapse arengut mitmesuguste enda koostatud materjalide abil, mitteeakohase tasemega laste arengu hindamisel loodavad aga eelkõige tugispetsialistidele ja nõustamiskeskustele (Paaliste, 2011; Palts \& Häidkind, 2014).

Siinse uurimuse aluseks on küsimus, kuivorrd realistlikud on eelkirjeldatud viisil määratletud eeldatavad arengutulemused, millest lähtudes teevad õpetajad oma igapäevatööd koolieelsetes lasteasutustes üle Eesti. Keskendume 3-4aastastele lastele, sest selles vanuses on enamik neist alustanud lasteaiateed ning nende eakohaseid oskusi mõjutavad üha enam õpetajate pakutavad õppe- 
ja kasvatustegevused. Lisaks võimaldab arengu hindamine lasteaias usaldusväärsemalt välja selgitada need lapsed, kes vajavad tõhusamat toetust.

\section{Sotsiaalsed ja enesekohased oskused}

Sotsiaalne kompetentsus on võime teistega suhelda ja suhteid luua ning selle kaudu oma eesmärke saavutada (Hart, Newell, \& Olsen, 2003; Sheridan, Knoche, Edwards, Bovaird, \& Kupzyk, 2010). Sotsiaalsed ja enesekohased oskused moodustavad ühe osa sotsiaalsest kompetentsusest, aidates kaasa lahenduste leidmisele suhtlusolukordades ning emotsioonide äratundmisele ja reguleerimisele (Hart, DeWolf, Wozniak, \& Burts, 1992). Nende oskuste asjakohane kasutamine soodustab toimetulekut olukordades, kus eeldatakse oskust enda käitumist juhtida, seda situatsioonile ja üldteada tavadele vastavalt kohandada (Merrell \& Gimpel, 1998). Lisaks on teada, et sotsiaalsete oskuste kõrgem tase lasteaiaeas on seotud hilisema õppeedukusega (nt McClelland, Acock, \& Morrison, 2006).

Merrell ja Gimpel (1998) on koondanud varem tehtud uuringute tulemused ja rühmitanud sotsiaalsed oskused nende peamise funktsiooni järgi. Tulemuseks on viis kategooriat: eakaaslastega suhtlemine (nt ühistegevustes osalemine), enese käitumise juhtimine (nt frustratsioonitaluvus), õppeedukus (nt ülesandele orienteeritus), kuulekus (nt kokkulepetest kinni pidamine) ja juhtimisoskused (nt initsiatiivi haaramine). Siiski ei ole tegemist oskuste rühmadega, mida saaks üksteisest täielikult eristada. Nii võib kuulekust pidada üheks õppeedukusega seotud teguriks, sest kokkulepetest kinni pidamine hõlmab reeglite järgimist ning see omakorda aitab kaasa õppetegevuses osalemisele. Positiivse oskuse puudumine või oskuse liiga madal või kõrge tase võib lapse käitumises avalduda negatiivsena. Näiteks võib lapsel olla soov algatada kaaslastega koosmängu, kuid ta võib seda teha niivõrd domineerivalt, et kaaslased tunnetavad seda pealetükkiva käitumisena, mitte positiivsete juhtimisoskuste avaldumisena.

Michelson, Sugai, Wood ja Kazdin (1983) on välja pakkunud, et sotsiaalsed oskused on jälgimise ja jäljendamise kaudu õpitud käitumine. Õppimise ajal on oluline saada käitumisele tagasisidet selle kohta, kas teistega suhtlus algas ja kulges ladusalt ning tõhusalt (selline käsitusviis toetub Võgotski arenguteooriale, vt Carpendale \& Lewis, 2004). Sotsiaalsed oskused ilmnevad nii verbaalse kui ka mitteverbaalse jälgitava käitumisena. Sotsiaalsete oskuste kasutamine sõltub suhtlussituatsioonis osalevate inimeste omadustest, keskkonnast ja situatsioonist (Michelson et al., 1983). Lasteaiaõpetajatel on unikaalne võimalus jälgida laste sotsiaalsete oskuste kasutamist suhtlussituatsioonides, mis varieeruvad nii osalejate (nt eakaaslased, täiskasvanud) kui ka sisu poolest (nt rutiinsed tegevused, konfliktid) (Jones, Greenberg, \& Crowley, 2015). 
Eelkooliealiste laste puhul on oluline, et nad õpiksid eristama ja teadvustama peale enda oskuste ja tunnete ka teiste omi, sest see võimaldab neil juhtida enda käitumist ning adekvaatselt olukorrale reageerida (Männamaa \& Marats, 2009). Näiteks kui laps suudab märgata, et teine on kurb, ja taibata, kas teine vajab abistamist või lohutamist, ning seejärel asuda asjakohaselt tegutsema, siis võib pidada tema enesekohaseid ja sotsiaalseid oskusi väga heaks. Männamaa ja Maratsi (2009) käsitluse järgi on ootuspärane, et 3aastaste laste meeleolu vaheldub kiiresti ning nad püüavad teha kindlaks, milline käitumine on lubatud ja milline lubamatu. Nad suudavad teistega lühikest aega koos tegutseda ning mõnikord järgida ühise tegutsemise reegleid, näiteks oodata oma korda. 4aastastel peaks 3aastastega võrreldes olema parem arusaamine teiste inimeste tunnetest ning kõrgemal tasemel oskus juhtida enda käitumist.

Vahel võib märgata vajakajäämisi sotsiaalsetes oskustes või seda, et oskusi rakendatakse ülemäära intensiivselt, kaaslasi ja olukorda arvesse võtmata. Näiteks on ühes uurimuses leitud, et peaaegu poolte lasteaiaõpetajate hinnangul on pooltel nende rühma lastest sotsiaalsete oskuste tase madal (Rimm-Kaufman, Pianta, \& Cox, 2000). Õpetajal ei pruugi olla lihtne hinnata lapse sotsiaalseid oskusi, kui ei ole teada, milline on nende taseme ootuspärane jaotus teatud vanuse piires. Väikelapse eas on oskuste varieeruvus tavapärane (Merrell, 1994) ning sellises olukorras võib olla keeruline otsustada, kas erinevust keskmisest tasemest võib veel pidada oskuse eakohaseks kasutamiseks või on tegemist eripäraga, millele tuleks rohkem tähelepanu pöörata. Seetõttu on oluline teada, milliseid sotsiaalseid ja enesekohaseid oskusi 3-4aastased lapsed igapäevastes lasteaiaolukordades kasutatavad.

\section{Tunnetus- ja õpioskused}

Tunnetustegevus ehk kognitsioon on see osa psüühikast, mis tegeleb otseselt infotöötlusega, võimaldades inimesel ümbritsevast maailmast infot vastu võtta ja seda mõtestada. Infotöötluseks rakendame taju-, mälu-, mõtlemis- ja tähelepanuprotsesse (vt nt Bjorklund \& Causey, 2017; Gleitman, Gross, \& Reisberg, 2014; Smith \& Kosslyn, 2015). Taju muundab meeltele mõjuva stimulatsiooni korrastatud ja mõtestatud infoks, mille tulemusel eristab laps näiteks katkematus visuaalsete ärritajate voos tuttavaid objekte. Mäluoskustest sõltub, mida oma kogemustest, millisel kujul ja kui kaua suudab laps meeles pidada ning kui kergesti saab ta selle vajaduse korral kasutamiseks kätte. Mõtlemine võimaldab infot uudsetel viisidel kombineerida ning jõuda seeläbi tajutust ja mällu salvestatust isikupäraste kujutluste ja tõlgendusteni maailmas toimuva kohta. Tähelepanuoskustest sõltub, mis valitakse keskkonnast edasiseks töötluseks välja ja kui kauaks jääb see fookusesse. 
Nimetatud oskused ei ole selgepiiriliselt üksteisest eristatavad, sest kognitiivsed protsessid on tihedas koostoimes. Veelgi enam, infotöötlusoskustena sisalduvad nad ka kõigis oskustes, mida laps õpib eri õppe- ja kasvatustegevuse valdkondades. Kuna tunnetusoskustest sõltuvad suurel määral laste mistahes tegevus ja selle tulemused, siis peaksid õpetajad alustama nende toetamist juba siis, kui laps jõuab lasteaeda. Tunnetustegevust otseselt jälgida ega hinnata ei saa, kuid nende oskuste kohta on võimalik teha järeldusi, jälgides erinevaid käitumisviise (Bjorklund \& Causey, 2017) kas loomulikus olukorras (vaatlus) või teadlikult neid esile kutsudes (testid ja eksperimendid).

Koolieelse lasteasutuse riiklikus õppekavas (2008) on tunnetusoskustega kõrvuti esitatud ka õpioskused. Siia kuuluvad soov tegutseda koos täiskasvanuga ja järgida juhiseid; valmisolek ja oskus uurida, katsetada ning hankida ise uusi teadmisi; oskus harjutada õpitavat, küsida ja kasutada abi. Õpioskused põhinevad tunnetusoskustel, kuid suurel määral on kaasatud ka motivatsioon ning emotsioonid (Brigman \& Webb, 2003; McClelland et al., 2006).

Tunnetus- ja õpioskuste arenguks on oluline optimaalne keskkondlik stimulatsioon - nii sotsiaalne kui ka füüsiline. Juba vastsündinud reageerivad keskkonnas toimuvatele muutustele ning need esialgu üsna piiratud ja diferentseerumata reaktsioonid muutuvad lapse arengu käigus peenekoelisemaks ja oma seesmiselt ülesehituselt järjest keerukamaks (Toomela, 2017). 3-4aastaste laste tunnetusoskuste repertuaar on juba päris lai (ülevaateks vt nt Galotti, 2017; Goswami, 2008). Nende tajuoskused võimaldavad eristada objekte värvuse, suuruse ja kuju alusel ning terviktaju lubab kokku panna lihtsamaid puslesid (Strebeleva, 2010; Taverna \& Peralta, 2013). 3-4aastased lapsed toetuvad tegutsedes enam mälukujutlustele, räägivad asjadest, mida pole läheduses, kasutavad mälu ja ka lihtsamaid mälustrateegiaid teadmiste omandamiseks ja kogetu meenutamiseks (Männamaa \& Marats, 2009; Waismeyer \& Jacobs, 2013). Mõtlemisoskustest on 3-4aastaste laste puhul oluline mainida kõige põhilisemaid: analüüsi- ja sünteesioskusi, võrdlemist, järjestamist ning rühmitamist (Strebeleva, 2010). Asjade ja sündmuste vahelisi varjatud seoseid aitavad mõista arutlus- ja järeldamisoskused, mis on juba kõnest sõltuvad ja kõnes väljenduvad ning 3-4aastastel lastel veel suhteliselt vähesed (Koerber, Sodian, Thoermer, \& Nett, 2013).

3-4aastased lapsed on valdavalt tegevusliku (kaemuslik-praktilise) mõtlemise etapis (Strebeleva, 2010) ja seega väljenduvad ka nende tunnetusoskused suurel määral tegevustes: nad kõrvutavad ja rivistavad objekte ning grupeerivad neid eri viisidel. Vanuse kasvades muutub laste mõtlemine kõneliselt vahendatuks ning nad töötlevad infot järjest enam vaimses plaanis, mida on õpetajal väliselt palju keerulisem analüüsida. 


\section{Mänguoskused}

Mängu olemuse üle on arutletud kaua ja põhjalikult. Käsitlustes rõhutatakse mängu kui lapse põhitegevust, mis on paindlik ja vabatahtlik ning pakub talle naudingut (Whitebread, 2017). Mängu käsitletakse ka kui üht valdkonda, mida saab arendada (Wallerstedt \& Pramling, 2012) ja mille vahendusel õpib laps kõige efektiivsemalt (Fesseha \& Pyle, 2016; Hegde, Sugita, Crane-Mitchell, \& Averett, 2013; Pyle \& Bigelow, 2014). Mängides lõimib laps loovalt seda, mida ta juba oskab, katsetab uusi teadmisi ja oskusi ning õpib juurde nii kogemustest kui ka kaaslastelt.

Mänguoskused hõlmavad mängude liike, mänguepisoodide kestust, lapse algatusvõimet ja loovust, reeglite järgimise ja kokkulepete tegemise oskusi, toimetulekut kaotusega võistlusmängudes. Neid oskusi saab nii arendada kui ka hinnata (Koolieelse lasteasutuse riiklik õppekava, 2008; Palts \& Häidkind, 2014). Ka sellest loetelust on näha, et mänguoskused seostuvad tihedalt nii tunnetus- ja õpioskustega kui ka sotsiaalsete ja enesekohaste oskustega. Seega saab oskuslik vaatleja mängiva lapse tegutsemist jälgides rikkalikku infot erinevate üldoskuste, samuti ainealaste (matemaatika, kunst jt) teadmiste ja oskuste arengutaseme kohta.

Kui 1-2aastane laps tegutseb eelkõige esemetega, õppides neid teiste inimeste eeskujul kasutama funktsioonikohaselt, efektiivsemalt ja motoorselt osavamalt, siis 3-4aastane laps hakkab mängima koos teise lapsega. Lapsed võtavad endale mingid rollid ja koostöös hakkab arenema lugu, mis haarab osalisi kaasa ja muutub vastavalt laste arengule üha keerukamaks (Niilo \& Kikas, 2008; Tiko, 2006). Ugaste jt (2008) on kirjeldanud eesti laste mänguoskuste arenemist rolli-, lavastus-, ehitus- ja õppemängude kaupa. Lasteaiaõpetaja saab mänguoskuste arengut toetada seeläbi, et tutvustab lapsele ümbritsevat maailma (õppekäigud, õppe- ja kasvatustegevused), õpetab kasutama mänguvahendeid, pakub mänguideid ja mudeldab rolle. 3-4aastane laps vajab õpetaja abi ka teise lapsega koostööd tehes, sest tema konfliktilahendusoskused on lihtsakoelised. Õpetaja saab kinnitada ja tunnustada sobilikke kaaslasega käitumise viise, õpetada keerukamaid töövõtteid (ehitus- ja õppemängus) ning raskuste korral mängus otseselt osaleda (rolli- ja lavastusmängus).

Kokkuvõtteks võib öelda, et laste mängu- ja ka teiste üldoskuste sihipärane arendamine eeldab lasteaiaõpetajalt järkjärgulist edasiliikumist, mille korral lähtutakse lapse olemasolevatest oskustest (Barton, 2016; Michelson et al., 1983; Strebeleva, 2010). Kui lapse üldoskusi hinnata enne õpetamist ja tema oskuste tase on eeldatavast madalam või kõrgem, tuleb õpetajal oma tööd lapse tasemele vastavalt kohandada. Seega on lapse üldoskuste taseme adekvaatne hindamine üks kvaliteetse õpetamise tingimusi, seda nii üldoskuste kui ka õppe- ja kasvatustegevuse valdkondade toetamisel. Õpetamise järel tasub 
hinnata, kuivõrd see on aidanud kaasa eeldatavate arengutulemuste saavutamisele (Häidkind et al., 2014; McConnell \& Rahn, 2016). Sel viisil saab õpetaja tööst paremini aru ka lapsevanem.

\section{Empiiriline uurimus}

Üldoskuste olemust koolieelses eas on mõnel määral käsitletud (Männamaa \& Marats, 2009; Niilo \& Kikas, 2008; Palts \& Häidkind, 2014; Ugaste et al., 2008), kuid laste üldoskuste teadlikuks arendamiseks ja usaldusväärseks hindamiseks vajavad lasteaiaõpetajad täpsemaid orientiire. Praegu tuleb koolieelse lasteasutuse riiklikku õppekava (2008) aluseks võttes igas koolieelses lasteasutuses kohapeal määratleda üldoskuste eeldatav tase igaks eluaastaks (v.a 6-7aastased lapsed) ning valida hindamismeetodid ja -vahendid. Peamine hindamismeetod on vaatlus. Ka vaatluse puhul on oluline, et õpetajal oleks tõenduspõhine alus, millest lähtudes otsustada, kas lapse tegevuses ilmnevad oskused vastavad eakohasele tasemele.

Uurimuse eesmärk on kirjeldada 3-4aastaste eesti laste üldoskuste taset kõigis koolieelse lasteasutuse riiklikus õppekavas (2008) toodud üldoskuste valdkondades ja kõrvutada saadud tulemusi õpetajatele koostatud juhendmaterjalides olevate eeldatavate arengutulemustega. Analüüsime, kuivõrd meie kasutatud hindamisvahenditega saadud tulemused kattuvad Riikliku Eksamija Kvalifikatsioonikeskuse välja antud juhendmaterjalides (peatükkide autorid Muldma \& Kiilu, 2008; Männamaa \& Marats, 2009; Oja, 2008; Oll, 2008; Sikka, 2008; Ugaste et al., 2008) esitatud kirjeldustega 3- ja 4aastaste laste oskuste kohta, ning osutame, mida lasteaiaõpetaja võiks laste arengu hindamisel ja toetamisel arvesse võtta.

3-4aastaste eesti laste oskuste hindamiseks kasutasime kolme hindamisvahendit: sotsiaalseid ja enesekohaseid oskusi hindasime õpetajate täidetud küsimustikuga, tunnetus- ja õpioskusi Strebeleva metoodikaga (Strebeleva, Mišina, Razenkova, Orlova, \& Šmatko, 2005) ning mänguoskusi ja üldarengut laiemalt psühholoogilis-pedagoogilise profiili abil (edaspidi PEP-3 test; Schopler, Lansing, Reichler, \& Marcus, 2005). Teadaolevalt on see esimene kord kirjeldada empiirilisel alusel eesti 3-4aastaste laste üldoskusi kõigi koolieelse lasteasutuse riiklikus õppekavas (2008) toodud valdkondade lõikes. Hüpotees ja uurimisküsimused olid hindamisvahendite kaupa järgmised.

1. Oletame, et välja töötatud sotsiaalsete oskuste küsimustikku kuuluvad väited jagunevad Merrelli ja Gimpeli (1998) välja pakutud sotsiaalsete oskuste klassifikatsiooni kohaselt viide rühma. Kas 3-4aastaste laste sotsiaalsete oskuste küsimustiku tulemustes on vanuselised ja soolised erinevused ning millised need on? Milline on sotsiaalsete oskuste küsimustikku koondatud 
tegevuste kasutussagedus 3-4aastaste laste hulgas, lähtudes õpetajate antud hinnangutest?

2. Milline on 3-4aastaste eesti laste tunnetus- ja õpioskuste tase Strebeleva metoodika alusel?

3. Millised vanuserühmade ja sugude vahelised erinevused ilmnevad 3- ja 4aastaste eesti laste PEP-3 testi arenguskaala tulemustes?

\section{Meetod}

\section{Valim}

Esmalt küsisime lasteaedade direktoritelt nõusolekut asutuse kaasamiseks uuringusse. Kui see oli saadud, küsisime nõusolekut osalemiseks nii laste õpetajatelt kui ka lapsevanematelt. Valimisse kaasasime vaid need lapsed $(N=839)$, kelle osalemisega olid vanemad nõus ja kes käisid sellises rühmas, mille õpetaja oli samuti nõus uuringus osalema. Lasteaiad paiknesid eri piirkondades üle Eesti: Harju-, Jõgeva-, Lääne-, Pärnu-, Rapla-, Tartu-, Valga- ja Võrumaal. 3/4 lastest elas linnades ja 1/4 valdades. Andmeid kogusid meie juhendamisel magistritöid tegevad üliõpilased ajavahemikul märtsist 2015 kuni veebruarini 2016.

Lapsed käisid sõime- ja lasteaiarühmades ning õpetajate ja lapsevanemate hinnangul ei olnud neil ilmnenud õppimist mõjutavaid erivajadusi (sh kakskeelsus), samuti ei vajanud nad logopeedilist abi. Kõik lapsed rääkisid lapsevanematelt saadud info kohaselt emakeelena eesti keelt. 71\% sotsiaalsete oskuste küsimustiku täitnud õpetajatest andis teada, et nad tunnevad konkreetset last hästi või väga hästi. Laste sooline ja vanuseline jaotus kasutatud hindamisvahendi kaupa on toodud tabelis 1 (valimid omavahel ei kattunud).

Tabel 1. Valimisse kuulunud laste sooline ja vanuseline jaotus kasutatud hindamisvahendi kaupa

\begin{tabular}{ccccccccccc}
\hline & \multicolumn{3}{c}{$\begin{array}{c}\text { Sotsiaalsete oskuste } \\
\text { küsimustik }\end{array}$} & \multicolumn{3}{c}{ Strebeleva metoodika } & \multicolumn{3}{c}{ PEP-3 test } \\
\hline \multicolumn{3}{c}{ Poisid Tüdrukud } & Kokku & Poisid & Tüdrukud & Kokku & Poisid & Tüdrukud & Kokku \\
\hline 3aastased & 150 & 144 & 294 & 55 & 54 & 109 & 39 & 37 & 76 \\
\hline 4aastased & 68 & 88 & 156 & 71 & 82 & 153 & 25 & 26 & 51 \\
\hline Kokku & 218 & 232 & 450 & 126 & 136 & 262 & 64 & 63 & 127 \\
\hline
\end{tabular}

Märkused. 3aastastel lastel oli vanusevahemik 3 aastat ja 0 kuud kuni 3 aastat ja 11 kuud; 4aastastel lastel 4 aastat ja 0 kuud kuni 4 aastat ja 11 kuud. Strebeleva metoodika tulemuste alusel valiti valimisse lapsed, kes kogusid 34-40 punkti (testikriteeriumide järgi on sellise skooriga lapsed eakohase arenguga). 


\section{Hindamisvahendid ja protseduur}

\section{Sotsiaalsete oskuste küsimustik}

Sotsiaalsete oskuste küsimustik on välja töötatud Tartu Ülikoolis koostöös tegevõpetajatega, tuginedes sotsiaalsete oskuste klassifikatsioonile (Merrell \& Gimpel, 1998) ning koolieelse lasteasutuse riiklikule õppekavale (2008). Arvestatud on lasteaiaõpetajate unikaalset võimalust jälgida laste käitumist (Jones et al., 2015). Eesmärk on anda lasteaiaõpetajatele lapse sotsiaalsete ja enesekohaste oskuste esmase hindamise vahend (vt täpsemalt Lilleoja, 2017; Marran, 2015).

Artikli aluseks olevas uuringus täitis üks rühmaõpetaja iga lapse kohta sotsiaalsete oskuste küsimustiku, mis koosneb neljast osast. Esimeses osas on 41 väidet, mis kirjeldavad tegevusi lapse sotsiaalsete ja enesekohaste oskuste kohta (nt „Käitub vastavalt viisakusreeglitele“). Teises osas on kuus väidet selle kohta, milline on lapse arusaam enda ja teiste mõtetes ning tunnetes toimuvast (nt „Ütleb, mida teine tunneb“). Rühmaõpetaja sai iga tegevuse puhul neljapunktisel Likerti skaalal (vahemikus 0 ehk „mitte kunagi“ kuni 3 ehk „peaaegu alati“) märkida, kui sageli on ta näinud last nimetatut tegemas, ja iga arusaama puhul, kui tihti ta on kuulnud last seda väljendamas. Kolmandas osas palusime õpetajal hinnata lapse arengutaset võrdluses eakaaslastega kuue sotsiaalsete oskustega seotud näitaja alusel (nt „Kas lapse sõnavara on võrreldes eakaaslaste omaga väiksem, sama suur või suurem?"). Neljandas osas küsisime ametialaseid taustandmeid õpetaja kohta (nt „Kui hästi õpetaja last tunneb?“).

\section{Strebeleva metoodika}

Laste kognitiivse arengu hindamiseks kasutasime Venemaa Haridusakadeemia Moskva korrektsioonipedagoogika instituudi professori J. A. Strebeleva välja töötatud metoodikat (Strebeleva et al., 2005). Valiku põhjus oli metoodika tuttavus Eesti lasteaiaõpetajatele ja tugispetsialistidele, uuritavate oskuste kattuvus koolieelse lasteasutuse riiklikus õppekavas (2008) ja sellega seotud juhendmaterjalides kirjeldatud oskustega ning see, et tegemist on standardiseeritud hindamisvahendiga.

2015. aastal kohandati metoodika koostöös selle autoriga Eesti kultuuri- ja keelekeskkonna jaoks sobivaks. Eesti laste tulemuste põhjal ajakohastati pildimaterjali ning täpsustati ülesannete läbiviimise ja skoorimise juhiseid. Kohandamisprotsessi, ülesannetes tehtud muudatuste ning nende põhjenduste kohta saab täpsemalt lugeda Tartu Ülikooli magistritöödest (Audo, 2015; Injukina \& Põldaru, 2016; Voolpriit, 2016). Meile teadaolevalt ei ole seda metoodikat varem teiste maade kontekstis kohandatud ega teadusuuringutes kasutatud. 
Metoodika koosneb eraldi ülesannetest 3- ja 4aastastele. Lapsega tehakse individuaalselt läbi 10 ülesannet (vt tabel 2), milleks kulub umbes 20 minutit. Iga ülesande sooritust hinnatakse 4, 3, 2 või 1 punktiga. 4 punkti saab laps iseseisva soorituse eest; 3 punkti saab laps siis, kui ta päris iseseisvalt hakkama ei saa, küll aga abistamise korral; 2 punkti saab laps juhul, kui ta mõistab ülesannet ja püüab seda lahendada, aga ebaõnnestub ka juhul, kui teda abistatakse; 1 punkti saab laps juhul, kui ta ei mõista ülesannet, tegutseb ülesande nõudmiste suhtes ebaadekvaatselt ja abistamisest ei ole kasu. Metoodikas on ette nähtud abistamine juhuks, kui laps iseseisvalt toime ei tule. Abiks on kas valmisnäidis või tegevusnäidis, mille korral täiskasvanu demonstreerib ja selgitab, kuidas ta ülesannet lahendab.

Tabel 2. Strebeleva metoodika ülesanded 3- ja 4aastastele lastele

\begin{tabular}{|c|c|}
\hline Ülesanne & Hinnatavad oskused \\
\hline \multicolumn{2}{|l|}{ 3-ja 4aastased } \\
\hline 1. Süžeemäng & Mänguoskused \\
\hline 2. Kujundikarp & $\begin{array}{l}\text { Kuju järgi võrdlemise oskus ning proovimise kui praktilise } \\
\text { ülesande lahendamise oskus }\end{array}$ \\
\hline 3. Lelude kokkupanek & Esemete võrdlemisel suurusele orienteerumise oskus \\
\hline 4. Pildi kokkupanek & Terviktaju- ja sünteesioskus \\
\hline 5. Joonistamine & $\begin{array}{l}\text { Esemelise joonistuse tase: 3aastastel õhupalli joonistamine, } \\
\text { 4aastastel inimese joonistamine }\end{array}$ \\
\hline 6. Piltide kirjeldamine & Süžeepiltide mõistmise ja kõne arengu tase \\
\hline 7. Piltide võrdlemine & Analüüsi-, võrdlemis- ja järeldamisoskus \\
\hline \multicolumn{2}{|l|}{ 3aastased } \\
\hline 8. Esemete rühmitamine & $\begin{array}{l}\text { Kuju eristamise ja kuju järgi võrdlemise oskus ning } \\
\text { rühmitamisoskus }\end{array}$ \\
\hline 9. Klotsidest ehitamine & $\begin{array}{l}\text { Tegevusnäidise järgi tegutsemise oskus ja analüüsi- } \\
\text { sünteesioskus }\end{array}$ \\
\hline 10. Probleemülesanne & Kaemuslik-praktilise mõtlemise tase \\
\hline \multicolumn{2}{|l|}{ 4aastased } \\
\hline 8. Loomade majad & Näidise järgi sihipäraselt tegutsemise oskus, samuti värvitaju \\
\hline 9. Pulkadest ehitamine & $\begin{array}{l}\text { Valmisnäidise järgi tegutsemise oskus ja analüüsi- } \\
\text { sünteesioskus }\end{array}$ \\
\hline 10. Arvutamine & Lapse kujutlused hulkadest \\
\hline
\end{tabular}

Märkus. Ülesanded 1-7 on oma tüübilt samad mõlemas vanuserühmas, seejuures kaks esimest ülesannet on identsed. 
Tulemuste alusel saab eristada eakohase arenguga, riskirühma ja vaimse arengu mahajäämusega lapsi. Eakohase arenguga laste tulemus on käsiraamatu alusel vahemikus 34-40 punkti ning nad lahendavad enamiku ülesannetest iseseisvalt.

\section{Psühholoogilis-pedagoogiline profiil (PEP-3 test)}

3-4aastaste laste üldarengu hindamiseks kasutasime USAs loodud vahendit PEP-3 test (Schopler et al., 2005), mida kohandasime samuti eesti laste jaoks (vt Leetsar, 2015; Niilus, 2016). Testiülesanded tõlgiti, lastele antavad korraldused ja uurimismaterjal muudeti eesti keele ja kultuuri konteksti sobivamaks. Kuigi originaaltesti normid on kogutud nii eakohaselt arenenud kui ka autisimispektrihäirega laste valimitel, on enamik uuringuid PEP-3 testiga mujal maailmas tehtud erivajadustega laste gruppides (De Giacomo et al., 2016; Fu, Chen, Tseng, Chiang, \& Hsieh, 2012).

Siinses eakohaselt arenevaid lapsi puudutavas artiklis käsitleme üksnes arenguskaala alltestide ülesannete tulemusi. Kokku oli lapsele võimalik testi käsiraamatu alusel pakkuda kuni 123 arenguskaala ülesannet, mis jagunesid kuueks alltestiks (vt tabel 3).

Tabel 3. PEP-3 testi arenguskaala alltestid

\begin{tabular}{lcl}
\hline Alltest & $\begin{array}{c}\text { Ülesannete } \\
\text { arv }\end{array}$ & Hinnatavad võimed ja oskused \\
\hline Kognitiiv-verbaalne areng & 34 & Kognitiivne areng, verbaalne mälu \\
\hline Kõne kasutamine & 25 & Eneseväljendus rääkimise või žestide abil \\
\hline Kõne mõistmine & 19 & Kõnest arusaamine \\
\hline Peenmotoorika & 20 & Kehaosade koostöö ja koordinatsioonivõime \\
\hline Üldmotoorika & 15 & Võime juhtida oma kehaosade liikumist \\
\hline Jäljendamine & 10 & $\begin{array}{l}\text { Oskus jäljendada visuaalseid ja motoorseid } \\
\text { tegevusi }\end{array}$ \\
\hline
\end{tabular}

Kõik need valdkonnad ja hinnatavad oskused on kokku viidavad koolieelse lasteasutuse riiklikus õppekavas (2008) olevate eeldatavate arengutulemustega üldoskuste valdkondades, kohati ka õppe- ja kasvatustegevuse valdkondades (keel ja kõne, kunst, matemaatika, mina ja keskkond, liikumine, muusika).

Skoorimisel lähtusime järgmistest reeglitest, mis on testi käsiraamatus ka täpsemalt lahti kirjutatud:

- edukas sooritus - laps suudab ülesande edukalt lahendada ega vaja ettenäitamist (2 punkti); 
- osaline sooritus - laps paistab mingil määral teadvat, kuidas ülesannet lahendada, kuid ei ole võimeline seda edukalt tegema, või tuleb testijal lapsele korduvalt ette näidata või õpetada, kuidas ülesannet lahendada (1 punkt);

- ebaõnnestunud sooritus - laps ei ole üldse võimeline ülesannet lahendama või ei ürita seda teha ka pärast korduvat ettenäitamist (0 punkti).

Lapsi testiti individuaalselt eraldi ruumis. Kuna testi reeglite järgi tuleb pakkuda lapsele iga alltesti ülesandeid kergemast raskemani nii palju, kui laps testija kaasabil kaasa töötab, ning test on tervikuna väga mahukas, siis jagasime ülesanded kahe testimiskorra vahel. Üks testimiskord kestis olenevalt lapse jõudlusest 25-40 min.

\section{Andmeanalüïs}

Sotsiaalsete oskuste küsimustiku esimese osa üksikväidete rühmitamiseks kasutasime faktoranalüüsi (Varimax normalized) koos pööramisega, et tuua võimalikult suurel määral esile faktorlaadungite varieeruvus eri faktoritel. Gruppide keskmisi tulemusi võrdlesime Mann-Whitney U-testi või sõltumatute valimite $T$-testiga. Strebeleva metoodika puhul hindasime vanuserühmade proportsioonide erinevust (difference between two proportions). Kõigi hindamisvahendite puhul kasutasime kirjeldavat statistikat, et illustreerida 3-4aastaste laste üldoskuste taset.

\section{Tulemused}

\section{Sotsiaalsete oskuste küsimustiku väidete jaotus}

Faktoranalüüsi tulemusena (vt lisad 1 ja 2) eristus viis faktorit (kumulatiivne protsent kogu variatiivsusest: 53,24\%). Neist esimesse ehk ópiedu faktorisse $(\alpha=0,88)$ kuuluvad 12 väidet sotsiaalsete oskuste kohta, mis on seotud kuulekuse ja õpieduga (nt „püüab kaaslastega kokkuleppeid sõlmida“). Teises ehk enesejuhtimise faktoris $(\alpha=0,85)$ on 8 väidet oskuste kohta, mis on seotud enesevalitsusega (nt „rahuneb kiiresti, kui on pahaseks saanud“). Kolmanda ehk kaaslastega suhete faktori $(\alpha=0,86)$ moodustavad 8 väidet oskuste kohta, mis hõlmavad kaaslastega koos tegutsemist (nt „lülitub kiiresti teiste mängu“). Neljandasse ehk osavuse faktorisse $(\alpha=0,60)$ kuuluvad 3 väidet osavuse kohta (nt „on eakaaslastega võrreldes kohmakas") ja viiendasse ehk enesekesksuse faktorisse $(\alpha=0,85) 7$ väidet enesekesksusega seonduva kohta (nt „segab teiste jutule vahele"). Kolm väidet 41 st ei laadunud ühelegi viiest faktorist 0,5 st suurema väärtusega. 


\section{3- ja 4aastaste poiste ja tüdrukute sotsiaalsete oskuste küsimustiku tulemuste võrdlus}

Selleks, et vanuserühmade ja sugude kaupa saadud tulemusi oleks hõlpsam kõrvutada, arvutasime iga faktori puhul aritmeetilise keskmise (vt tabel 4).

Tabel 4. Viie sotsiaalsete oskuste faktori keskmised tulemused õpetajate hinnangute kohaselt 3- ja 4aastastel poistel ja tüdrukutel

\begin{tabular}{|c|c|c|c|c|c|c|c|c|c|c|}
\hline & \multicolumn{2}{|c|}{ Õpiedu } & \multicolumn{2}{|c|}{$\begin{array}{l}\text { Enese- } \\
\text { juhtimine }\end{array}$} & \multicolumn{2}{|c|}{$\begin{array}{c}\text { Suhted } \\
\text { kaaslastega }\end{array}$} & \multicolumn{2}{|c|}{ Osavus } & \multicolumn{2}{|c|}{ Enesekesksus } \\
\hline & $M$ & $S D$ & $M$ & $S D$ & $M$ & $S D$ & $M$ & $S D$ & $M$ & $S D$ \\
\hline 3aastased & 2,08 & 0,54 & 1,20 & 0,58 & 2,14 & 0,60 & 0,88 & 0,70 & 1,18 & 0,66 \\
\hline poisid & $2,00^{*}$ & 0,54 & 1,21 & 0,59 & 2,13 & 0,60 & $1,01^{*}$ & 0,73 & 1,26 & 0,68 \\
\hline tüdrukud & $2,16^{*}$ & 0,54 & 1,21 & 0,58 & 2,14 & 0,60 & $0,75^{*}$ & 0,63 & 1,11 & 0,63 \\
\hline 4aastased & 2,08 & 0,50 & 1,32 & 0,63 & 2,01 & 0,60 & 0,97 & 0,69 & 1,17 & 0,63 \\
\hline poisid & 2,03 & 0,45 & 1,33 & 0,64 & 1,97 & 0,53 & 1,02 & 0,57 & 1,15 & 0,55 \\
\hline tüdrukud & 2,11 & 0,53 & 1,32 & 0,63 & 2.04 & 0,64 & 0,93 & 0,76 & 1,19 & 0,67 \\
\hline
\end{tabular}

Märkus. * tähistab sugudevahelist erinevust faktori keskmise tulemuse korral.

Kõigi faktorite skoorid jäid vahemikku 0-3 ehk iga faktori puhul leidus nii lapsi, kes said koondskooriks minimaalse võimaliku tulemuse, kui ka lapsi, kes said maksimaalse võimaliku tulemuse. Mida suurem oli ópiedu ja kaaslastega suhete faktori skoor, seda sagedamini kasutasid õpetajate hinnangul lapsed neisse faktoritesse kuuluvaid positiivseid sotsiaalseid oskusi. Mida väiksem oli enesejuhtimise, osavuse ja enesekesksuse faktori skoor, seda harvemini esines õpetajate hinnangul lastel negatiivselt mõjuvat käitumist.

Faktorite keskmiste tulemuste võrdlemisel ei ilmnenud 3- ja 4aastaste laste gruppide vahel statistiliselt olulisi erinevusi. Poiste ja tüdrukute vahelised erinevused tuvastasime ainult 3aastastel lastel ópiedu ja osavuse faktoris, kusjuures tüdrukud edestasid poisse mõlemal juhul (Mann-Whitney U-test: õpiedu $U=5890, Z=-2,54, p<0,05$, osavus $-U=6383, Z=2,96, p<0,005$; vt tabel 4). 4aastaste laste tulemustes olulisi sugudevahelisi erinevusi ei olnud.

\section{Laste sotsiaalsed ja enesekohased oskused õpetajate hinnangul}

Kuna vanuselised erinevused puuduvad ning soolised erinevused ei avaldunud 4aastastel samamoodi nagu 3aastastel, esitame järgneva kirjeldava info, mis põhineb rühmaõpetajate hinnangutel sotsiaalsete oskuste avaldumissagedusele 
kõigi 450 lapse korral. Iga üksikväite puhul olid õpetajad kasutanud hindamiseks kogu skaalat, seega ulatusid antud hinnangud nullist kolmeni. 3-4aastastel lastel seadsime oskuse omandatuse kriteeriumiks, et see ilmneb õpetajate hinnangul sageli ja peaaegu alati vähemalt $80 \%$ lastest.

Eeltoodust tulenevalt on ópiedu faktorisse kuuluvate oskuste puhul ootuspärane, et laps jutustab hiljuti toimunud sündmustest, käitub viisakusreeglite kohaselt, järgib mängureegleid, alustab vestlusi, oskab teistega ära leppida ja küsib täiskasvanult abi. Enesejuhtimises on 3-4aastase lapse oskused veel arengujärgus, vaid teiste suhtes agressiivse käitumise korral on ootuspärane, et laps suudab end pidurdada. Kaaslastega suheldes naeravad 3-4aastased sageli, kui teised nalja teevad, nad hoiavad harva teistest eemale ning mängivad tihti lihtsamaid rollimänge. Osavuse faktoris ei hinnanud õpetajad ühegi väite puhul esinemissageduseks vähemalt $80 \%$. Enesekesksuse faktorisse kuuluvad väited näitavad, et 3-4aastase lapse oskused arenevad veel ja õpetajate hinnangul ei rakendata ühegi väite puhul oskust sageli.

Tabelis 5 on toodud oskused, mille puhul õpetajad andsid väga harva äärmuslikke kasutamissageduse hinnanguid. Oluline on, et õpetaja märkaks lapsi, kelle oskused erinevad eakaaslaste omadest märkimisväärselt (nt last, kes pöördub väga harva täiskasvanu poole abi küsimiseks).

Tabel 5. Sotsiaalsete ja enesekohaste oskuste kriitiline avaldumissagedus 3-4aastastel lastel õpetajate hinnangute kohaselt

\begin{tabular}{lccccccc}
\hline & & & & \multicolumn{4}{c}{$\begin{array}{c}\text { Protsent lastest, kelle } \\
\text { sagedushinnang oli }\end{array}$} \\
\cline { 5 - 8 } & $N$ & $M$ & $S D$ & 0 & 1 & 2 & 3 \\
\hline $\begin{array}{l}\text { käitub vastavalt viisakusreeglitele } \\
\text { (nt tänab ja teretab) }\end{array}$ & 450 & 2,17 & 0,77 & 2,66 & 16,41 & 45,01 & 35,70 \\
\hline oskab teistega ära leppida & 439 & 2,16 & 0,76 & 2,66 & 14,63 & 47,23 & 32,82 \\
\hline küsib täiskasvanult abi & 447 & 2,39 & 0,66 & 1,11 & 7,54 & 44,12 & 46,34 \\
\hline naerab, kui teised nalja teevad & 446 & 2,42 & 0,70 & 1,33 & 10,20 & 35,48 & 51,88 \\
\hline hoiab rühmakaaslastest eemale & 448 & 0,67 & 0,81 & 53,44 & 30,16 & 13,08 & 2,66 \\
\hline
\end{tabular}

Märkused. 0 - õpetaja hinnangul mitte kunagi, 3 - õpetaja hinnangul peaaegu alati. Üksikväidete kaupa on esitatud tulemused, mille puhul äärmuslikud hinnangud jäävad kas madalamale 20 protsentiili tasemest või ületavad 80 protsentiili taseme. 


\section{Laste tunnetus- ja õpioskused Strebeleva metoodika alusel}

Et vastata uurimisküsimusele, milline on 3-4aastaste eesti laste tunnetus- ja õpioskuste tase Strebeleva metoodika tulemuste alusel, arvutasime iga ülesande kohta, mitu protsenti lastest lahendas selle iseseisvalt ja mitu protsenti lastest vajas õnnestunud tulemuse saavutamiseks abi. Samuti leidsime nende laste osakaalud, kes küll püüdsid ülesannet lahendada, kuid ebaõnnestusid ka abistamise korral, ning need, kes ei mõistnud ülesande sisu isegi abistamise korral ja kelle tegevus oli seetõttu ebaadekvaatne. 3aastaste laste tulemused on esitatud tabelis 6 ja 4 aastaste omad tabelis 7 .

Tabel 6. 3aastaste laste tulemused Strebeleva metoodika korral

\begin{tabular}{lcccccc}
\hline \multirow{2}{*}{ Ülesanne } & \multirow{2}{*}{ M } & SD & \multicolumn{4}{c}{ Protsent laste arvust } \\
\cline { 6 - 8 } & & & 1 punkt & 2 punkti & 3 punkti & 4 punkti \\
\hline Süžeemäng & 3,63 & 0,63 & 0,92 & 5,50 & 22,94 & 70,64 \\
\hline Kujundikarp & 3,80 & 0,40 & & & 20,18 & 79,82 \\
\hline Lelude kokkupanek & 3,79 & 0,49 & & 3,67 & 13,76 & 82,57 \\
\hline Pildi kokkupanek & 3,52 & 0,66 & 0,92 & 6,42 & 32,11 & 60,55 \\
\hline Joonistamine & 3,96 & 0,19 & & & 6,67 & 93,33 \\
\hline Piltide kirjeldamine & 3,76 & 0,53 & & 4,58 & 14,67 & 80,73 \\
\hline Piltide võrdlemine & 3,06 & 0,70 & 0,92 & 18,35 & 54,13 & 26,61 \\
\hline Esemete rühmitamine & 3,77 & 0,46 & & 1,83 & 19,27 & 78,90 \\
\hline Klotsidest ehitamine & 3,75 & 0,51 & 0,92 & 0,92 & 20,18 & 77,98 \\
\hline Probleemülesanne & 3,84 & 0,40 & & 0,92 & 13,76 & 85,32 \\
\hline
\end{tabular}

Märkus. 1 punkt - ebaadekvaatne sooritus, 2 punkti - abistamise korral ebaõnnestunud sooritus, 3 punkti - abistamise korral õnnestunud sooritus, 4 punkti - iseseisev sooritus.

Nagu näha, lahendab 92,7-100\% eakohase arenguga 3aastastest eesti lastest kümnest ülesandest üheksa kas abiga või iseseisvalt. Kõige raskem oli piltide võrdlemise ülesanne, millega ei saanud 19,3\% lastest hakkama ka juhul, kui neid abistati. Iseseisvalt suutis selle ülesande lahendada vaid $26,6 \%$ lastest. Samas oli $54,1 \%$ uuritud lastest võimelised pilte võrdlema, kui neid selles juhendati, mis näitab, et see oskus on neil kujunemisjärgus. Raskeks osutus ka pildi kokkupaneku ülesanne, kus kolmandik lapsi vajas abi. Ülejäänud kaheksa ülesannet sooritas 70,6-93,3\% eakohase arenguga lastest iseseisvalt, kõige lihtsam oli joonistamise ülesanne. 
Tabel 7. 4aastaste laste tulemused Strebeleva metoodika korral

\begin{tabular}{lcccccc}
\hline \multirow{2}{*}{ Ülesanne } & \multirow{2}{*}{ S } & SD & \multicolumn{4}{c}{ Protsent laste arvust } \\
\cline { 6 - 8 } & & & 1 punkt & 2 punkti & 3 punkti & 4 punkti \\
\hline Süžeemäng & 3,96 & 0,69 & 1,96 & 7,19 & 11,11 & 79,74 \\
\hline Kujundikarp & 3,95 & 0,22 & & & 5,23 & 94,77 \\
\hline Lelude kokkupanek & 3,86 & 0,38 & & 1,31 & 11,11 & 87,58 \\
\hline Pildi kokkupanek & 3,95 & 0,24 & & 0,65 & 3,27 & 96,08 \\
\hline Joonistamine & 3,65 & 0,60 & 1,31 & 2,61 & 26,14 & 69,93 \\
\hline Piltide kirjeldamine & 3,04 & 0,64 & 0,65 & 16,99 & 61,44 & 20,92 \\
\hline Piltide võrdlemine & 2,98 & 0,71 & 1,31 & 22,22 & 53,59 & 22,87 \\
\hline Loomade majad & 3,92 & 0,29 & & 0,65 & 6,54 & 92,81 \\
\hline Pulkadest ehitamine & 3,86 & 0,37 & & 1,31 & 9,80 & 88,89 \\
\hline Arvutamine & 3,56 & 0,60 & & 5,88 & 32,03 & 62,09 \\
\hline
\end{tabular}

Märkus. 1 punkt - ebaadekvaatne sooritus, 2 punkti - abistamise korral ebaõnnestunud sooritus, 3 punkti - abistamise korral õnnestunud sooritus, 4 punkti - iseseisev sooritus.

4aastaste laste jaoks olid kõige keerulisemad piltide kirjeldamise ja piltide võrdlemise ülesanne. Kummagi ülesandega sai iseseisvalt hakkama vaid 1/5 eakohase arenguga lastest. Abi kasutades sooritasid need ülesanded vastavalt $53,6 \%$ ja 61,4\% lastest. Kuna enamikul lastest oli siiski juhendamisest kasu, võib öelda, et pildimaterjali mõistmine ja selle alusel rääkimine on 3-4aastastel eesti lastel kujunemas. 1/3 lastest vajas abi arvutamisülesandes, mis näitab, et ka viie piires lahutamiseks vajaminevad oskused ei ole selles vanuses päris kindlalt veel omandatud. Ülejäänud seitsme ülesande iseseisva soorituse protsent jäi vahemikku 69,9-96,1. Kõige lihtsamaks osutus pildi kokkupaneku ülesanne.

Mõlema vanuserühma lastel olid kaks ülesannet - süžeemängu ja kujundikarbi ülesanne - täpselt ühesugused, mistõttu nende ülesannete lõikes saab võrrelda ka 3- ja 4aastaste oskusi omavahel. Võttes arvesse valimite suurusi, selgus maksimumpunktid saanud laste osakaalude võrdlemisel (difference between two proportions), et need ülesanded eristavad noorema ja vanema vanuserühma lapsi: kujundikarbi ülesanne olulisusnivool $p<0,001$ ning mänguoskuste ülesanne olulisusnivool $p<0,05$. 


\section{Vanuserühmade ja sugude vahelised erinevused laste PEP-3 testi tulemustes}

PEP-3 testi arenguskaala ülesannete keskmiste tulemuste võrdlemisel sõltumatute valimite $T$-testiga ilmnesid 3- ja 4aastaste laste gruppide vahel statistiliselt olulised erinevused kõigis alltestides, v.a üldmotoorika alltest. Poiste ja tüdrukute keskmiste tulemuste võrdlemisel selgus, et 3 aastaste vanuserühmas soolisi erinevusi pole. 4aastaste vanuserühmas oli üksnes kognitiiv-verbaalse arengu alltesti keskmine tulemus tüdrukutel statistiliselt oluliselt kõrgem kui poistel (vt tabel 8).

Tabel 8. PEP-3 testi gruppide vahelised keskmiste tulemuste erinevused vanuse ja soo alusel

\begin{tabular}{cccccccccccccc}
\hline & $\begin{array}{c}\text { Kognitiiv- } \\
\text { verbaalne } \\
\text { areng }\end{array}$ & \multicolumn{2}{c}{$\begin{array}{c}\text { Kõne } \\
\text { kasutamine }\end{array}$} & \multicolumn{2}{c}{$\begin{array}{c}\text { Kõne } \\
\text { mõistmine }\end{array}$} & $\begin{array}{c}\text { Peen- } \\
\text { motoorika }\end{array}$ & $\begin{array}{c}\text { Üld- } \\
\text { motoorika }\end{array}$ & $\begin{array}{c}\text { Jäljenda- } \\
\text { mine }\end{array}$ \\
\hline & $M$ & $S D$ & $M$ & $S D$ & $M$ & $S D$ & $M$ & $S D$ & $M$ & $S D$ & $M$ & $S D$ \\
\hline 3aastased & $49,80^{* *}$ & 7,30 & $31,32^{* *}$ & 4,30 & $34,03^{* *}$ & 3,07 & $36,22^{* *}$ & 2,79 & 28,63 & 3,06 & $17,89^{*}$ & 2,51 \\
\hline poisid & 49,74 & 5,30 & 31,51 & 3,19 & 34,13 & 1,91 & 36,46 & 1,80 & 28,74 & 2,90 & 18,15 & 1,87 \\
\hline tüdrukud & 49,86 & 9,03 & 31,11 & 5,27 & 33,92 & 3,97 & 35,97 & 3,56 & 28,51 & 3,25 & 17,62 & 3,04 \\
\hline 4aastased & $57,94^{* *}$ & 6,05 & $34,10^{* *}$ & 3,81 & $35,76^{* *}$ & 1,76 & $38,20^{* *}$ & 1,60 & 29,29 & 1,29 & $18,92^{*}$ & 1,55 \\
\hline poisid & $55,84^{*}$ & 6,85 & 33,48 & 4,25 & 35,44 & 1,96 & 37,80 & 1,61 & 29,12 & 1,62 & 18,72 & 1,86 \\
\hline tüdrukud & $59,96^{*}$ & 4,41 & 34,69 & 3,31 & 36,08 & 1,52 & 38,58 & 1,53 & 29,46 & 0,86 & 19,12 & 1,18 \\
\hline
\end{tabular}

Märkused. 3- ja 4aastaste laste keskmise tulemuse erinevuse olulisusnivoo: ${ }^{*}-p<0,05 ;{ }^{* *}-p<0,001$. Mõlema vanuserühma poiste ja tüdrukute keskmise tulemuse erinevuse olulisusnivoo: ${ }^{*}-p<0,05$; $^{* *}-$ $p<0,001$.

Järgnevalt kirjeldame eakohase arenguga 3- ja 4aastaste laste tulemusi üheskoos PEP-3 arenguskaala alltestide kaupa. Toome välja ülesanded, mille sooritas vähemalt $50 \%$ lastest iseseisvalt, ülejäänud vajasid mõnevõrra abi. Tegemist on eakohaste oskustega, mida enamik eesti lapsi neis vanuserühmades valdab, st neid on efektiivne arendada ja mõttekas ka hinnata. Ülesandeid, mida lapsed sooritasid nõrgemal tasemel, ja ülesandeid, mida kõik lapsed sooritasid iseseisvalt edukalt, me siinkohal ei kajasta.

Kognitiiv-verbaalse arengu alltestis võib eeltoodud kriteeriumi alusel pidada 3aastastele lastele eakohaseks mitmesuguseid tajuülesandeid, näiteks neljaosalise sakiliste servadega pusle kokkupanek, esemete ja piltide omavaheline sobitamine, tähtede sobitamine kuju alusel, värviliste klotside sobitamine samasugustele alustele. Mäluülesannetest olid eakohased esemete funktsiooni demonstreerimine ning silpide, sõnade, lausete ja arvude järelekordamine. 
Mõtlemisprotsesside rakendamist oli tarvis, kui lapsel tuli ühendada inimese kujutis tervikuks kaheksast tükist, sorteerida esemeid kahte hulka. 4aastastel lastel (nii poiste kui ka tüdrukute grupis ühtemoodi) lisandusid eeltoodud loetelusse kaks joonistusülesannet: vertikaaljoone ja ringi järeletegemine, mis 3 aastastele olid veel liiga rasked (edukalt sooritas need 35,5\% ja 34,2\% 3aastastest lastest ning 68,6\% ja 64,7\% 4aastastest lastest).

Kõne kasutamise alltesti ülesanded osutusid 3aastastele lastele teiste alltestidega võrreldes raskeks: ühtki selle alltesti ülesannet ei sooritanud kõik 3 aastased lapsed maksimumtulemusele. Eakohasteks oskusteks võib tulemuste alusel pidada niisuguste ülesannete täitmist, kus laps pidi vastama küsimusele üksiksõnaga (värvuste, suuruste nimetamine, oma nime, soo ütlemine), kasutama lausungeid. Mõnevõrra üllatavalt ei lisandunud 4aastaste laste puhul uusi ülesandeid, mis oleksid enamikule neist eakohased.

Kõne mõistmise alltestis osutusid eakohasteks oskusteks näiteks korralduse alusel iseenda ja nuku kehaosade näitamine, esemetele ja piltidele osutamine, verbaalsete juhiste täitmine, küsimustele vastamine ja värvuste nimetuste mõistmine. 4aastastel lisandus siia loetelusse geomeetriliste kujundite (ringi, ruudu, kolmnurga) nimetuste mõistmine (44,7\% 3aastastest ja 66,7\% 4aastastest lastest sooritasid ülesande edukalt).

Peenmotoorika alltestis said kõik 3aastased lapsed iseseisvalt hakkama esemete paigutamisega süvenditesse kuju ja suuruse alusel (valikuks 3-4 elementi). Eakohased olid erinevad liigutused, silma-käe koostööd ja kahe käe koostööd eeldavad tegevused, nt kääridega lõikamine, purgikaane keeramine, klotside ladumine, pärlite lükkimine. 3aastastel lastel oli välja kujunenud domineeriv silm (laps eelistas kaleidoskoopi vaadata püsivalt sama silmaga). 4aastastele lastele olid lisaks eakohased pintsetthaarde kasutamine väikeste esemetega tegutsemisel (35,5\% 3aastastest ja 64,7\% 4aastastest sooritasid ülesande edukalt) ning geomeetriliste kujundite ülejoonistamise ülesanne (30,3\% 3aastastest ja 76,5\% 4aastastest sooritasid ülesande edukalt).

Üldmotoorika ja jäljendamise alltestis olid kõik ülesanded 3- ja 4aastastele lastele ühtmoodi eakohased. Vaid üksikud lapsed ei sooritanud neid ja võib oletada, et põhjus ei olnud oskuste puudumises, vaid soovimatuses teha koostööd testijaga, kes oli võõras. Kokkuvõtvalt võib öelda, et juba 4. eluaasta alguseks on lapsel välja kujunenud domineeriv jalg ja käsi ning ta tegutseb üsna osavalt palliga, joob iseseisvalt tassist ja liigub vahelduva sammuga trepist üles. Lapsed oskasid jäljendada nii kuulmise kui ka nägemise vahendusel saadud näidistegevusi, liikumisi. Mõnevõrra raske oli täpselt jäljendada kuuldud lauakella helinat (51,4\% 3aastastest ja 82,4\% 4aastastest sooritasid ülesande edukalt). 


\section{Arutelu}

Järgnevalt üldistame kolme hindamisvahendiga saadud tulemused, toome välja eakohased oskuste rühmad üldoskuste valdkondade kaupa ja vaatame, kuidas täpsustus 3-4aastaste eesti laste üldoskuste tase võrreldes eeldatavate arengutulemustega, mis on esitatud õpetajatele koostatud juhendmaterjalides. Et üldoskuste tase avaldub muu hulgas õppe- ja kasvatustegevuse valdkondade kaudu, arutleme tulemuste üle, aktsepteerides seda seost (Botting \& Marshall, 2017; Knops et al., 2017).

\section{3-4aastaste laste sotsiaalsed ja enesekohased oskused}

Sotsiaalsete oskustega seoses soovisime esmalt teada, kas sotsiaalsete oskuste küsimustikku kuuluvad väited jagunevad rühmadesse kooskõlas Merrelli ja Gimpeli (1998) välja pakutud positiivsete sotsiaalsete oskuste klassifikatsiooniga. Uurimistulemusena leidsime viie faktoriga lahendi, mis kattub suures osas eelnimetatud klassifikatsiooniga. Nagu positiivsete sotsiaalsete oskuste klassifikatsiooni puhul, kuuluvad ka meie lahendis eraldi rühmadesse väited, mis kirjeldavad sotsiaalseid oskusi, mida on vaja edukaks suhtlemiseks kaaslastega (pro eakaaslastega suhtlemise oskused), ning oskusi, mille vajakajäämine viib enesevalitsemisega seotud raskusteni (pro enese käitumise juhtimise oskused) ja liigse enesekesksuseni (pro juhtimisoskused).

Õppeedukuse ja kuulekusega seotud väited moodustasid Merrelli ja Gimpeli (1998) klassifikatsiooni alusel kaks eraldi rühma, aga meil koondusid need ühte faktorisse. Merrell ja Gimpel (1998) on märkinud, et nende leitud kategooriad ei ole selgepiirilised ning seega ei ole nende kahe kategooria üheks koondumine üllatav. Siiski on oluline seda tulemust tõlgendades mõtelda, kas see võiks osutada kultuuri eripärale ehk kas eesti õpetajad võivad eeldada, et õppetegevustele orienteeritud lapsed on ühtlasi sõnakuulelikud. Lisaks kuuluvad meie klassifikatsioonis viiendasse faktorisse kolm väidet, mis puudutavad lapse motoorset osavust (või selle puudumist) ja püsivust pingutust nõudvate tegevuste puhul. Niisugust kategooriat Merrelli ja Gimpeli (1998) klassifikatsioonis ei ole. Erinevuse põhjus võib olla see, et sotsiaalsete oskuste küsimustikus sisalduvad muude hulgas väited, mille puhul eeldasime, et need võivad mõjutada laste sotsiaalset toimetulekut, kuigi tegemist ei ole otseselt sotsiaalsete oskustega (nt kohmakat, ettearvamatu käitumise või napi eneseväljendusoskusega last ei pruugi teised mängukaaslaseks soovida).

Järgmiseks võrdlesime õpetajate hinnanguid 3- ja 4aastaste poiste ning tüdrukute sotsiaalsete ja enesekohaste oskuste kasutamise sageduse kohta. Me ei leidnud neis süsteemseid erinevusi. Vanuserühmadevaheliste erinevuste puudumine võib tulla näiteks sellest, et selles vanuses laste oskused on suure 
variatiivsusega (Merrell, 1994), mistõttu vanuserühmasisesed erinevused on suuremad kui vanustevahelised erinevused. Teisalt võib vanustevaheliste erinevuste puudumist seletada sellega, et vanemate laste puhul on rühmaõpetajate ootused suuremad, ning kuigi 4aastased võivad olla sotsiaalsete oskuste kasutamisel 3aastastest osavamad, hindavad õpetajad oskuste kasutamise sagedust vastavalt oma suurenenud ootustele (vt ka Jones et al., 2015).

Järgmise sammuna kõrvutasime õpetajate hinnanguid laste sotsiaalsete ja enesekohaste oskuste kasutamise sagedusele koolieelsete lasteasutuste jaoks koostatud juhendmaterjalis tooduga. Männamaa ja Marats (2009) osutavad selles juhendis, et 3aastase lapse meeleolu vaheldub kiiresti ning asjade jagamise ja oma järjekorra ootamise oskus avalduvad pigem harva. Meie uuringus ilmnes samuti, et lastel ei ole veel välja kujunenud oskused, kuidas oma käitumist juhtida ning enesekesksust ületada. 4aastase lapse puhul kirjeldavad Männamaa ja Marats (2009), et võib juhtuda, et laps räägib end huvitavatel teemadel ilma kaaslasi kuulamata. Õpetajate hinnangute kohaselt soovib aga laps pigem algatada vestlust ning kõneleda hiljuti toimunud sündmustest, mitte ei eelista ise rääkida, kuulamata teisi. Siiski võib juhtuda, et ühevõrra õhinas olevad vestluskaaslased keskenduvad pigem oma kogemuste jagamisele ning teise kuulamine jääb seejuures kõrvaliseks. Männamaa ja Marats (2009) on toonud 4aastaste puhul välja, et lapsed oskavad käituda viisakusreeglite järgi, ning sama leidsime meiegi.

Mõeldes sotsiaalsete oskuste küsimustikuga saadud tulemuste rakenduslikule väärtusele, pöördume üksikväidetega seotud tulemuste juurde. Rühmaõpetajatel tuleks olla tähelepanelik nende laste suhtes, kes käituvad õpetaja hinnangul väitekohasel viisil väga harva nende oskuste puhul, mis moodustavad eduka sotsiaalse suhtluse aluse (nt laps ei algata kunagi või algatab väga harva ise vestlusi), või väga sageli nende oskuste puhul, mille ülemäärane rakendamine põhjustab raskusi sotsiaalses suhtluses (nt laps hoiab peaaegu alati või sageli rühmakaaslastest eemale). Seejuures on kohane lugejale meenutada, et lapse oskuste kohta üldistuste tegemiseks on vaja, et ta saaks äärmuslikke hinnanguid enamiku väidete puhul, mis kuuluvad kokku, kuid ka sel juhul võib leiduda lapsi, kelle tulemused on ülejäänud faktorite korral siiski ootuspärased. Soovitame lasteaiaõpetajatel küsimustikku kasutada eelkõige selleks, et sõeluda välja õpetamist vajavad sotsiaalsed ja enesekohased oskused.

\section{3-4aastaste laste tunnetus- ja õpioskused}

Tunnetus- ja õpioskuste taseme kohta saime põhilise informatsiooni Strebeleva metoodika, aga ka PEP-3 testi tulemuste kaudu. Sissejuhatuses kirjeldatud definitsiooni (Brigman \& Webb, 2003; Gleitman et al., 2014; McClelland et al., 
2006; Smith \& Kosslyn, 2015) alusel kuulub siia valdkonda tunnetusprotsesside, emotsioonide ja motivatsiooniga seotud ülesannete lahendamine.

Strebeleva metoodika hindamiskriteeriumide järgi peaksid eakohase arenguga laste oskused olema piisavad, et lahendada ülesanded iseseisvalt (Strebeleva et al., 2005). Meie uuritud 3-4aastaste laste tunnetus- ja õpioskuste tase haakub selle eeldusega enamiku ülesannete korral. Vaid pildimaterjali analüüsimise ja võrdlemise oskused ning arvutamisoskused olid lastel nõrgemad ja nad vajasid abi. Võimalik, et sellise ebaootuspärase tulemuse põhjus on Venemaa ja Eesti lasteaedade õppesisu ja -korralduse erinevused või see, et hindamismetoodika töötati välja kaks kümnendit tagasi.

PEP-3 testi arenguskaala alltestide tulemusi võrreldes selgus, et vanuserühm mõjutab tulemusi ulatuslikumalt kui lapse sugu. Tulemus on ootuspärane, kuna 4aastaste laste kokkupuude ümbritseva maailmaga ning võimalus seda uurida ja oma võimeid katsetada on pikemaajalisem. Testitulemuste alusel ei toimunud olulist arengunihet kolmes alltestis: kõne kasutamine, üldmotoorika ja jäljendamine. On võimalik, et üldarengu hindamiseks mõeldud test jäi siinkohal liialt pinnapealseks, st et erinevuste leidmiseks on vaja spetsiifilisemaid vahendeid (nt kõnetest, vt Padrik, Hallap, \& Raudik, 2016). See, kas tegemist on poisi või tüdrukuga, ei paista Eesti kultuurikontekstis avaldavat olulist mõju laste oskuste tasemele. Üksnes kognitiiv-verbaalse arengu alltestis olid 4aastased tüdrukud sama vanadest poistest kokkuvõttes edukamad. Sellele, et tüdrukute verbaalne võimekus on poiste omast paremal tasemel, on viidanud mitmed uuringud ka varem (Eriksson et al., 2012).

Lasteaiaõpetajad saavad uurimuse tulemuste alusel oma igapäevatöös laste tunnetus- ja õpioskuste arendamisel arvesse võtta järgmist. 3aastased eesti lapsed suudavad eristada objekte kuju, värvuse või suuruse alusel, kui võrreldavaid elemente on korraga 5-6. Neljandal eluaastal kasutavad lapsed kahtluste korral enamasti katse ja eksituse meetodit, viiendal eluaastal leiavad lihtsama/ tuttavama kujuga klotsidele sobiva avause juba üksnes visuaalse võrdlemise teel. Juhendmaterjalis, kus käsitletakse matemaatika valdkonda (Sikka, 2008), on kirjas, et laps suudab võrrelda/järjestada 2-3 objekti (pole märgitud, kas muus osas on objektide tunnused samad). Männamaa ja Marats (2009) märgivad aga, et 4aastaseks saanud laps „keskendub tegutsedes mitmele nähtavale ja eristatavale tunnusele ning jaotab oma tähelepanu" (lk 22). Seega, matemaatika valdkonnas oodatakse 3-4aastaselt lapselt justkui oluliselt vähem, kui ta oma tunnetus- ja õpioskuste tasemest lähtudes suudab.

Mis puudutab selliste terminite mõistmist ja kasutamist, mis tähistavad visuaalselt tajutavaid tunnuseid, siis värvuste nimetusi ja mõisteid suur ja väike mõistab ning kasutab siinse uurimuse alusel edukalt enamik 3aastaseid lapsi, levinumate geomeetriliste kujundite nimetused on arusaadavad aga alles 
4aastastele. Samas eeldatakse matemaatika valdkonnas 4aastaselt lapselt, et ta oskaks kirjeldada ruudu ja ristküliku sarnasusi ja erinevusi (Sikka, 2008). Kui lapsel pole kujundite nimetused korralikult kinnistunud, siis detailselt ei suuda ta neid kujundeid veel analüüsida.

Õppekava juhendmaterjali järgi on ootuspärane, et 4-5aastane laps oskab jagada objekte nende tunnuste alusel kahte rühma (Sikka, 2008). Seevastu Strebeleva metoodika rakendamisel praeguses uuringus ilmnes, et juba 3aastased lapsed oskavad iseseisvalt võrrelda erikujulisi esemeid etalonkujundiga ning rühmitada erinevate geomeetriliste kujunditega sarnanevaid esemeid. 3aastaste oskust eristada ruutu, ringi ja kolmnurka kinnitab ka Zambrzycka, Kotsopoulose, Lee ja Makoszi uurimus (2017). PEP-3 testi tegemisel oli samuti enamikule 3aastastest lastest lihtne rühmitada objekte kahte hulka ning nad rühmitasid nii värvuse, suuruse kui kuju alusel objekte edukalt kuni 3-4 hulka.

Terviktaju ja sünteesioskust läheb lastel vaja mitmesuguste pusletaoliste ülesannete tegemisel. Praeguses uuringus kasutati Strebeleva metoodikat rakendades üksnes sirgete servadega pusletükke (3-4 osa), PEP-3 testis aga ka sakiliste servadega tükke (4 osa). Selgus, et ligi pooled 3aastastest lastest vajavad kolmeosalise sirgete servadega pildi tervikuks tegemisel abi, samal ajal aga neljaosalise sakiliste servadega pildi panevad nad kokku raskusteta. 4aastased lapsed panevad iseseisvalt kokku neljaks lõigatud esemepildi, mis kujutab tuttavat objekti (Strebeleva metoodika), kuueosaline pilt PEP-3 testis on aga neile liiga raske. Õppekava juhendmaterjalides sellise detailsusastmega juhiseid tükipiltide kohta kahjuks praegu ei ole, kuigi erinevaid puslesid on lasteaedades ja kodudes tänapäeval rohkesti.

Konstrueerimisoskusi sisaldab ka joonistamine, kuid siin tuleb vajaminevad detailid ise tekitada. Kui Strebeleva metoodika alusel suudavad 3aastased eakohase arenguga lapsed raskusteta joonistada näidise järgi nii ringi kui ka kriipsu ja need omavahel ühendada, siis PEP-3 testi tulemused olid siinkohal erinevad. Alles 4aastased suutsid järele joonistada korrektset vertikaaljoont ja ringi, lisaks üle joonistada keerukamaid geomeetrilisi kujundeid (ruut, kolmnurk, romb). Samasugune erinevus ilmnes nende kahe hindamisvahendiga saadud tulemuste vahel inimese joonistamise ülesandes: Strebeleva metoodika puhul oskas enamik 4aastaseid lapsi joonistada inimest nii, et kõik olulisimad kehaosad on olemas ja omavahel õiges asetuses, kuid PEP-3 testi tulemuste alusel oli tervikliku inimese joonistamise oskus 4aastastel lastel alles kujunemisjärgus. Samas oskas enamik 4aastaseid lapsi nimetuste alusel osutada enda ja käpiknuku kehaosadele, ühendada tervikuks kaheksaosalise inimese kujutise, st teadmised inimese kehast olid lastel olemas.

PEP-3 testi alusel võib öelda, et juba 3aastaselt on lapsel selgelt eristunud juhtiv silm, käsi ja jalg ning ta valdab üha paremini mitmesuguseid kunstitegevusi 
(sh lõikab kääridega, rullib plastiliini ja lükib pärleid nöörile). 4aastaselt lisandub pintsetthaarde kasutamine väikeste esemete võtmiseks. Õppekava juhendmaterjalis on kunstivaldkonnas (Oll, 2008) 3aastaste laste oskuste kirjeldus eeltooduga sarnane, 4aastaste laste oskusi ei kirjeldata aga juhendis üldse.

Männamaa ja Maratsi (2009) seisukoht on, et 5. eluaasta lópuks „oskab laps vaadelda ja märgata detaile, olulisi tunnuseid ja seoseid“ (lk 29). Siinse uurimuse tulemused nii julget üldistust vähemalt pildimaterjali kasutamisel ei toeta. PEP-3 testi kaudu selgus, et 3aastaste laste huvi pildiraamatu uurimise vastu on suur. Nii PEP-3 testi kui ka Strebeleva metoodika abil saime teada, et 3aastased lapsed suudavad mõista, nimetada ja kirjeldada lihtsaid eseme- ja tegevuspilte (vt ka Masterson, Druks, \& Gallienne, 2008), kuid erinevaid pilte nad omavahel võrrelda veel ei oska. 4aastased vajavad abi süžeepildi kirjeldamisel ning selles, et leida pildil üles oluline info ja teha selle põhjal asjakohaseid järeldusi. Kuna ligi $80 \%$ eakohase arenguga lastest ei ole nendeks tegevusteks veel iseseisvalt võimelised, siis tuleb abivajadust pidada eakohaseks ja lasteaiaõpetajad peaksid pildimaterjaliga töötades pakkuma nii 3- kui ka 4aastastele lastele sihipäraselt abi.

Väikesed lapsed õpivad uusi oskusi väga ulatuslikult eeskuju toel, mistõttu võib jäljendamisoskust pidada üheks olulisimaks õppimist mõjutavaks oskuseks. Nii pole üllatav, et jäljendamise kohta olid olemas väited, ülesanded ja/ või abistamisviisid kõigis kasutatud hindamisvahendites. Õpetajatele koostatud juhendmaterjalides viidatakse 3-4aastaste laste jäljendamisoskustele aga ainult muusika- ja liikumistegevusi puudutavates peatükkides (Muldma \& Kiilu, 2008; Oja, 2008). Ka oma uuringust PEP-3 testiga saime teada, et 3aastased lapsed suudavad järele teha nii ühe- kui ka kaheosalisi üldkehalisi harjutusi, rõõmustavad laulmise üle ning jäljendavad erinevaid käelisi tegevusi. Strebeleva metoodika kasutamisel selgus, et 3aastased lapsed konstrueerivad kolmest eri kujuga klotsist tegevusnäidise järgi lihtsa ehitise. Sarnase tulemuseni jõudsid ka Verdine jt (2014). 4aastased oskavad viiest pulgast konstrueerida kujundi valmis näidise järgi, st ilma et nad näeksid, kuidas pulki üksteise suhtes asetatakse. Kuigi Strebeleva originaalmetoodika alusel peaksid 4aastased lapsed oskama näidise järgi sihipäraselt tegutseda (ülesanne „Loomade majad“), selgus, et enamik lastest tuleb sellega toime juhul, kui neid juhendada, kuidas näidise järgi tegutseda. Seega tuleb arvestada, et pelgalt näidise etteandmisest 3-4aastastele lastele ei piisa ja nad vajavad selle järgimiseks juhendamist. Sotsiaalsete oskuste küsimustikus oli väide „matkib kaaslasi“ ning üle poole 3-4aastastest lastest seda õpetaja arvates sageli või peaaegu alati ka tegid.

Õppimise käigus on loomulik teha vigu ja vajada abi. Männamaa ja Marats (2009) märgivad, et 5. eluaasta lõpuks laps „tegutseb lühikest aega iseseisvalt, kuid tegutsemiskindluse saavutamiseks vajab veel täiskasvanu abi“ (lk 28). 
Praeguses uuringus olid nii Strebeleva metoodika kui ka PEP-3 test õpetusliku komponendiga hindamisvahendid, sest kõigis ülesannetes pakuti lapsele vajaduse korral abi ning arvestati seda ka tulemuste kodeerimisel. Peale näidiste ja eeskuju rakendati mõlema hindamisvahendi puhul laste abistamiseks ka verbaalseid juhiseid. Verbaalse juhise mõistmiseks on lapsel vaja sellele keskenduda, kuuldu meelde jätta ja sellest aru saada. 3aastased lapsed suutsid PEP-3 testis järele korrata vähe laiendatud lihtlauseid ja täita nii ühe- kui ka kaheosalisi juhiseid, vajaduse korral oskasid nad ka testijale märku anda, et nad vajavad abi.

Sotsiaalsete oskuste küsimustikus vastasid õpetajad, et enamik lapsi küsib abi sageli või peaaegu alati, paljud lapsed ootavad õpetajalt oma tegevusele heakskiitu (küsivad „Kas nii on õige?"). Strebeleva metoodika tulemused kinnitasid samuti, et eale vastavalt vajavad 3-4aastased lapsed verbaalset julgustamist. Lapsele ei öelda ette, mida ta peab täpselt tegema, vaid teda tuleb julgustada edasi mõtlema, proovima ja vaatlema.

\section{3-4aastaste laste mänguoskused}

Laste mänguoskused ilmnesid kõigi kasutatud hindamisvahenditega saadud tulemuste hulgas. Koolieelsetele lasteasutustele koostatud juhendmaterjalis märgivad Ugaste jt (2008), et neljandal eluaastal kujuneb rollimäng - laps võtab kellegi rolli ja tegutseb sellele omaselt. Mängul on süžee, milleks lapsed saavad ideid nii igapäevaelust, televiisorist, lugudest kui ka lasteaia õppetegevustest.

Süžeemängu ülesanne oli Strebeleva metoodikas järjekorras esimene. Nii 3- kui ka 4aastastele lastele pakuti valik mänguasju ning ergutati neist lugu arendama. Selgus, et juba 3aastased lapsed on osavad demonstreerima, milleks üks või teine mänguasi on mõeldud: nuku- või ehitusmänguks sobivad lelud aktiveerisid lapsi piisavalt, nad asusid enamasti iseseisvalt tegutsema ning tegevustest kõnelema või vastasid täiskasvanu küsimustele oma tegevuse kohta. Ootuspäraselt leidsime, et 4aastased on neis oskustes veelgi vilunumad. Ka PEP-3 testis oskasid 3aastased lapsed käpiknukul kasutada igapäevaelust tuttavaid eneseteeninduse vahendeid (nuuskasid mängult nuku nina, pesid hambaid, kammisid pead jne). Samuti osutus juba 3aastastele lastele eakohaseks lihtsa rolli võtmine ja rollisuhtlus (kahe tegelasega mängus). Mänguoskuste täielikumaks avaldumiseks oli testimisolukord mõnevõrra ebatavaline ning lapsed hoidsid end arvatavasti tagasi.

Omaette mänguliigina saame siinkohal välja tuua liikumismängud. PEP-3 testi tulemusena selgus, et 3 aastased eesti lapsed on üldmotoorselt osavad. Kõigi alltesti ülesannetega tuli iseseisvalt toime vähemalt $80 \%$ lastest. Lapsed oskasid mitmel moel tegutseda palliga, hüpata koosjalu, seista ühel jalal ilma 
kuhugi toetumata. Ka koolieelsetele lasteasutustele koostatud juhendmaterjalis (Oja, 2008) on kirjas, et 4aastane laps sooritab tasakaalu ja osavust arendavaid harjutusi ning kuni neljast harjutusest koosnevaid kombinatsioone ja kasutab sihipäraselt abivahendeid. Juba 2aastaselt peaks laps suutma hüpitada käes palli ja selle suunda jälgida. Seega võib järeldada, et tänu Eesti lasteaedades pakutavatele suhteliselt rasketele liikumistegevustele ületab laste üldmotoorse arengu tase PEP-3 testis oodatavat. Teine selgitus võib olla, et test on koostatud autismispektrihäirega lastele, kelle motoorne areng kulgeb aeglasemalt, ja arvestatud on ealise miinimumiga (Dadgar et al., 2017).

Teiste lastega mängimise oskuste kohta saime informatsiooni õpetajate vahendusel, kasutades sotsiaalsete oskuste küsimustikku. Männamaa ja Maratsi (2009) järgi osaleb laps neljanda eluaasta lõpuks rolli- ja võistlusmängudes, teeb teiste lastega koostööd; viienda eluaasta lõpuks aga osaleb eri liiki mängudes ja fantaseerib ning teda motiveerivad tegevused koos eakaaslastega. Leidsime, et õpetajate hinnangul järgivad lapsed sageli mängureegleid, mis soodustab koostööd teistega, ning samuti on 3-4aastaste laste puhul ootuspärane, et nad mängivad rollimänge, mis kajastavad igapäevaseid tegevusi, ehk nad suudavad kasutada fantaasiat. Lisaks meeldib selles vanuses lastele tegutseda koos eakaaslastega, sest lapsed hoiavad õpetajate hinnangul harva teistest eemale.

\section{Kokkuvõtteks}

Üks meie uurimuse väärtusi on suur üle-eestiline valim. Olukorras, kus koolieelse lasteasutuse õpetajate peamine hindamismeetod on vaatlus, rakendasime nii küsitlus- kui ka testimeetodit. Nii on saadud teave 3-4aastaste laste kohta mahukas ja mitmekesine. Oluline on keskenduda üldoskuste valdkondadele, kuna need on aluseks nii lapse arengu hindamisele kui ka õpetamiseks sobiva raskusastme leidmisele.

Uurimuse piirang on, et kolme hindamisvahendiga kogutud andmed pärinevad eri lastelt. See selgitab osaliselt mõningaid vastuolulisi tulemusi, kus samas vanuses lapsed lahendasid sarnase ülesande kahe hindamisvahendi korral erinevalt (nt inimese joonistamine).

Riikliku Eksami- ja Kvalifikatsioonikeskuse välja antud juhendmaterjalides (peatükkide autorid Muldma \& Kiilu, 2008; Männamaa \& Marats, 2009; Oja, 2008; Oll, 2008; Sikka, 2008; Ugaste et al., 2008) on eeldatavad arengutulemused sõnastatud üldiselt, lisaks varieeruvad vanusevahemikud, mille kaupa on eri valdkondades infot esitatud. Samuti ei ole arusaadav, kas tegemist on n-ö keskmise või miinimumtaseme kirjeldustega ning kas ja milliste üldoskuste korral on aastase vanusevahe puhul oodata märgatavaid erinevusi. See võib olla üks selgitus, miks meie tulemused ei olnud alati kooskõlas juhendmaterjalides 
esitatud kirjeldustega ning miks on koolieelse lasteasutuse õppekava koostamine keerukas (Ugaste et al., 2016). Üldoskuste hindamiseks (Jones et al., 2015; Rimm-Kaufman et al., 2000) ja toetamiseks (Häidkind et al., 2014) vajavad lasteaiaõpetajad usaldusväärset võrdlusalust.

Artiklis täpsustasime, millisel tasemel oskusi võiks 3-4aastaselt eakohaselt arenenud eesti lapselt üldoskuste valdkondades eeldada, kuidas (mis vahendite ja ülesannetega) saavad õpetajad seda taset hinnata ning milliseid eesmärke on asjakohane õpetades püstitada. Uuringuandmed võimaldavad läheneda lapse arengu hindamisele ja toetamisele senisest tõenduspõhisemalt.

\section{Tänusõnad}

Täname uuringus osalenud lasteaedasid ja perekondi ning andmeid kogunud üliõpilasi. Uuring toimus Tartu Ülikooli projekti „Vahendite loomine ja kohandamine eelkooliealiste laste arengu hindamiseks" raames ja seda rahastati Euroopa Majanduspiirkonna toetuste programmi „Riskilapsed ja -noored“ taotlusvoorust „Kaasamine ja sekkumised haridussüsteemis“. Programmi viisid üheskoos ellu Haridus- ja Teadusministeerium, Justiitsministeerium ja Sotsiaalministeerium.

\section{Kasutatud kirjandus}

Audo, K. (2015). J. Strebeleva metoodika 1.-5. ülesande sobivus 3-4-aastaste Eesti laste arengu psühholoogilis-pedagoogiliseks hindamiseks (magistritöö). Tartu: Tartu Ülikool.

Barton, E. E. (2016). Critical issues and promising practices for teaching play to young children with disabilities. In B. Reichow, B. A. Boyd, E. E. Barton, \& S. L. Odom (Eds.), Handbook of early childhood special education (pp. 267-286). Cham: Springer International Publishing Switzerland. https://doi.org/10.1007/978-3-319-28492-7_15

Bjorklund, D. F., \& Causey, K. B. (2017). Children's thinking: Cognitive development and individual differences. Los Angeles: SAGE Publications.

Botting, N., \& Marshall, C. (2017). Domain-specific and domain-general approaches to developmental disorders: The example of specific language impairment. In L. C. Centifanty \& D. M. Williams (Eds.), The Wiley handbook of developmental psychopathology (pp. 139-160). New York: Wiley Blackwell. https://doi.org/10.1002/9781118554470.ch6

Brigman, G. A., \& Webb, L. D. (2003). Ready to learn: Teaching kindergarten students school success skills. Journal of Educational Research, 96(5), 286-293. https://doi.org/10.1080/00220670309597641

Carpendale, J. I. M., \& Lewis, C. (2004). Constructing an understanding of mind: The development of children's social understanding within social interaction. Behavioral and Brain Sciences, 27(1), 79-96. https://doi.org/10.1017/S0140525X04000032 
Dadgar, H., Rad, J. A., Soleymani, Z., Khorammi, A., McCleery, J., \& Maroufizadeh, S. (2017). The relationship between motor, imitation, and early social communication skills in children with autism. Iran Journal of Psychiatry, 12(4), 233-237.

De Giacomo, A., Craig, F., Cristella, A., Terenzio, V., Buttiglione, M., \& Margar, L. (2016). Can PEP-3 provide a cognitive profile in children with ASD? A comparison between the developmental ages of PEP-3 and IQ of Leiter-R. Journal of Applied Research in Intellectual Disabilities, 29(6), 566-573. https://doi.org/10.1111/jar.12216

Eesti Vabariigi haridusseadus (1992). Riigi Teataja I, 12, 192. Külastatud aadressil https://www.riigiteataja.ee/akt/968165?leiaKehtiv.

Eriksson, M., Marschik, P. B., Tulviste, T., Almgren, M., Pérez Pereira, M., Wehberg, S., ... \& Gallego, C. (2012). Differences between girls and boys in emerging language skills: Evidence from 10 language communities. British Journal of Developmental Psychology, 30(2), 326-343. https://doi.org/10.1111/j.2044-835X.2011.02042.x

Fesseha, E., \& Pyle, A. (2016). Conceptualising play-based learning from kindergarten teachers' perspectives. International Journal of Early Years Education, 24(3), 361377. https://doi.org/10.1080/09669760.2016.1174105

Fu, C.-P., Chen, K. L., Tseng, M.-H., Chiang, F.-M., \& Hsieh, C.-L. (2012). Reliability and validity of the Psychoeducational Profile-third edition Caregiver Report in children with autism spectrum disorders. Research in Autism Spectrum Disorders, 6(1), 115-122. https://doi.org/10.1016/j.rasd.2011.03.011

Galotti, K. M. (2017). Cognitive development: Infancy through adolescence. Los Angeles: SAGE Publications.

Gleitman, H., Gross, J., \& Reisberg, D. (2014). Psühholoogia. Tartu: Hermes.

Goswami, U. C. (2008). Cognitive development: The learning brain. New York: Psychology Press.

Hart, C. H., DeWolf, M. D., Wozniak, P., \& Burts, D. C. (1992). Maternal and paternal disciplinary styles: Relations with preschoolers' playground behavioral orientations and peer status. Child Development, 63, 879-892. https://doi.org/10.2307/1131240

Hart, C. H., Newell, L. D., \& Olsen, S. F. (2003). Parenting skills and social-communicative competence in childhood. In J. O. Greene \& B. R. Burleson (Eds.), Handbook of communication and social interaction skills (pp. 753-797). Mahwah: Lawrence Erlbaum Associates.

Hegde, A. V., Sugita, C., Crane-Mitchell, L., \& Averett, P. (2013). Japanese nursery and kindergarten teachers' beliefs and practices. International Journal of Early Years Education, 22(3), 301-314. https://doi.org/10.1080/09669760.2014.948390

Häidkind, P., Palts, K., Pillmann, J., Ennok, K., Villems, K., \& Peterson, T. (2014). Lapse arengu hindamise ja toetamise juhendmaterjal koolieelsetele lasteasutustele. Tartu: Haridus- ja Teadusministeerium. Külastatud aadressil https://www.hm.ee/sites/default/files/juhendmaterjal_alusharidus.pdf.

Injukina, K., \& Põldaru, E. (2016). J.A. Strebeleva 4-aastaste laste üldarengu hindamise metoodika standardiseerimine (magistritöö). Tartu: Tartu Ülikool.

Jones, D. E., Greenberg, M., \& Crowly, M. (2015). Early social-emotional functioning and public health: The relationship between kindergarten social competence and future wellness. American Journal of Public Health, 105(11), 2283-2290.

https://doi.org/10.2105/AJPH.2015.302630 
Kikas, E. (2014). Projekt „Üldpädevused ja nende hindamine“. Ülevaade projektist ja mõningaid 7.-9. klasside uurimuse tulemusi. Tallinn: Tallinna Ülikool. Külastatud aadressil http://dspace.ut.ee/bitstream/handle/10062/49704/YPKoondAruanne. pdf? sequence $=1$ \&isAllowed $=y$.

Knops, A., Nuerk, A.-C., \& Göbel, S. M. (2017). Domain-general factors influencing numerical and arithmetic processing. Journal of Numerical Cognition, 3(2), 112132. https://doi.org/10.5964/jnc.v3i2.159

Koerber, S., Sodian, B., Thoermer, C., \& Nett, U. (2005). Scientific reasoning in young children: Preschoolers' ability to evaluate covariation evidence. Swiss Journal of Psychology, 64(3), 141-152. https://doi.org/10.1024/1421-0185.64.3.141

Koolieelse lasteasutuse riiklik õppekava (2008). Riigi Teataja I, 23, 152. Külastatud aadressil https://www.riigiteataja.ee/akt/13351772.

Leetsar, K. (2015). PEP-3 testi kõneülesannete sobivus 1-6-aastastele eesti lastele (magistritöö). Tartu: Tartu Ülikool.

Lilleoja, L. (2017). Oppetajate poolt 3-4-aastaste laste sotsiaalsetele oskustele antud hinnangute seos lapse kõne arengu ja kasvukeskkonnaga (magistritöö). Tartu: Tartu Ülikool.

Marran, T. (2015). 3-4aastaste laste sotsiaalsete oskuste esmane hindamine (magistritöö). Tartu: Tartu Ülikool.

Masterson, J., Druks, J., \& Gallienne, D. (2008). Object and action picture naming in three- and five-year-old children. Journal of Child Language, 35(2), 373-402. https://doi.org/10.1017/S0305000907008549

McClelland, M., Acock, A. C., \& Morrison, F. J. (2006). The impact of kindergarten learning-related social skills on academic achievement at the end of elementary school. Early Childhood Research Quarterly, 21, 471-490.

https://doi.org/10.1016/j.ecresq.2006.09.003

McConnell, S. R., \& Rahn, N. L. (2016). Assessment in early childhood special education. In B. Reichow, B. A. Boyd, E. E. Barton, \& S. L. Odom (Eds.), Handbook of early childhood special education (pp. 89-106). Switzerland: Springer International Publishing Switzerland. https://doi.org/10.1007/978-3-319-28492-7_6

Merrell, K. W. (1994). Preschool and kindergarten behavior scales. Test manual. Brandon: Clinical Psychology Publishing Company.

Merrell, K. W., \& Gimpel, G. A. (1998). Social skills of children and adolescents: Conceptualization, assessment, treatment. Mahwah: Lawrence Erlbaum Associates.

Michelson, L., Sugai, D., Wood, R., \& Kazdin, A. E. (1983). Social skills assessment and training with children: An empirically based handbook. New York: Plenum.

Muldma, M., \& Kiilu, K. (2008). Valdkond „Muusikaõpetus“. E. Kulderknup (koost.), Õppe- ja kasvatustegevuse valdkonnad (lk 91-107). Tallinn: Riiklik Eksami- ja Kvalifikatsioonikeskus.

Must, T. (2014). Laste arengu hindamine nelja Lõuna-Eesti maakonna lasteaia näitel (magistritöö). Tartu: Tartu Ülikool.

Männamaa, M., \& Marats, I. (2009). Lapse üldoskuste areng. E. Kulderknup (koost.), Üldoskuste areng koolieelses eas (lk 5-43). Tallinn: Riiklik Eksami- ja Kvalifikatsioonikeskus.

Neudorf, E., Ugaste, A., Tuul, M., \& Mikser, R. (2017). Lasteaiaõpetajate uskumused seoses laste üldoskuste arendamisega riikliku õppekava alusel: lisaseletus lasteaia koolistumise põhjustele. Eesti Haridusteaduste Ajakiri, 5(2), 54-79.

https://doi.org/10.12697/eha.2017.5.2.03 
Niilus, L. (2016). PEP-3 testi sobivus 6aastaste eakohase arenguga laste üldoskuste hindamiseks (magistritöö). Tartu: Tartu Ülikool.

Niilo, A., \& Kikas, E. (2008). Mäng. E. Kikas (toim.), Õppimine ja õpetamine koolieelses eas (lk 120-137). Tartu: Tartu Ülikooli Kirjastus.

Oja, L. (2008). Valdkond „Liikumine“. E. Kulderknup (koost.), Õppe- ja kasvatustegevuse valdkonnad (lk 108-116). Tallinn: Riiklik Eksami- ja Kvalifikatsioonikeskus.

Oll, T. (2008). Valdkond „Kunst“. E. Kulderknup (koost.), Õppe- ja kasvatustegevuse valdkonnad (lk 74-90). Tallinn: Riiklik Eksami- ja Kvalifikatsioonikeskus.

Paaliste, A. (2011). Koolieelses eas laste arengutaseme hindamine õppenõustamiskeskuste kogemusel (bakalaureusetöö). Tartu: Tartu Ülikool.

Padrik, M., Hallap, M., \& Raudik, S. (2016). 3-4aastaste eesti laste kõne grammatiline profiil. Eesti Haridusteaduste Ajakiri, 4(2), 30-59.

https://doi.org/10.12697/eha.2016.4.2.03

Palts, K., \& Häidkind, P. (2014). Lapse arengu hindamine ja koostöö lapsevanematega. P. Häidkind et al. (koost.), Lapse arengu hindamise ja toetamise juhendmaterjal koolieelsetele lasteasutustele (lk 7-29). Tartu: Haridus- ja Teadusministeerium. Külastatud aadressil

https://www.hm.ee/sites/default/files/juhendmaterjal_alusharidus.pdf.

Pyle, A., \& Bigelow, A. (2014). Play in kindergarten: An interview and observational study in three Canadian classrooms. Early Childhood Education Journal, 43(5), 385-393. https://doi.org/10.1007/s10643-014-0666-1

Rimm-Kaufman, S. E., Pianta, R. C., \& Cox, M. J. (2000). Teachers' judgments of success in the transition to kindergarten. Early Childhood Research Quarterly, 15(2), 147-166. https://doi.org/10.1016/S0885-2006(00)00049-1

Schopler, E., Lansing, M. D, Reichler, R. J., \& Marcus, L. M. (2005). Psychoeducational profile (3rd ed.). Texas: Shoal Creek Boulevard Austin.

Sheridan, S. M., Knoche, L. L., Edwards, C. P., Bovaird, J. A., \& Kupzyk, K. A. (2010). Parent engagement and school readiness: Effects of the getting ready intervention on preschool children's social-emotional competencies. Early Education and Development, 21(1), 125-156. https://doi.org/10.1080/10409280902783517

Sikka, H. (2008). Valdkond „Matemaatika“. E. Kulderknup (koost.), Õppe- ja kasvatustegevuse valdkonnad (lk 65-73). Tallinn: Riiklik Eksami- ja Kvalifikatsioonikeskus.

Smith, E. E., \& Kosslyn, S. M. (2015). Cognitive psychology: Mind and brain. Harlow: Pearson Education Limited.

Strebeleva, J. (2010). Mõtlemise kujundamisest arenguliste erivajadustega lastel. Eripedagoogi käsiraamat. Tartu: Atlex.

Strebeleva, E. A., Mišina, G. A., Razenkova, J. A., Orlova, A. N., \& Šmatko, N. D. (2005). Psihologo-pedagogitšeskaja diagnostika razvitija detei rannego i doškolnogo vozrasta. Metoditšseskoje posobie. Moskva: Prosvešenie.

Zambrzycka, J., Kotsopoulos, D., Lee, J., \& Makosz, S. (2017). In any way, shape, or form? Toddlers' understanding of shapes. Infant Behavior and Development, 46, 144-157. https://doi.org/10.1016/j.infbeh.2016.12.002

Taverna, A. S., \& Peralta, O. A. (2013). Young children category learning: A training study. European Journal of Psychology of Education, 28(3), 599-617.

https://doi.org/10.1007/s10212-012-0130-9 
Tiko, A. (2006). Lapse arengust ja selle jälgimisest. A. Tiko \& S. Almann (toim.), Arenguvestlused lasteaias (lk 5-47). Tallinn: Ilo.

Toomela, A. (2017). Minu Ise areng: inimlapsest Inimeseks. Struktuur-süsteemse psühholoogia alused II. Tartu: Väike Vanker.

Ugaste, A., Tuul, M., \& Välk, T. (2008). Mängu tähtsus lapse arengus ja mängu juhendamine. E. Kulderknup (koost.), Üldoskuste areng koolieelses eas (lk 44-62). Tallinn: Riiklik Eksami- ja Kvalifikatsioonikeskus.

Ugaste, A., Tuul, M., Mikser, R., Neudorf, E., \& Jürimäe, M. (2016). Koolieelse lasteasutuse õpetajate kui õppekava arendajate kogemused, ootused ja hinnangud. Eesti Haridusteaduste Ajakiri, 4(1), 92-118. https://doi.org/10.12697/eha.2016.4.1.04

Verdine, B. N., Golinkoff, R. M., Hirsh-Pasek, K., Newcombe, N. S., Filipowicz, A. T., \& Chang, A. (2014). Deconstructing building blocks: Preschoolers' spatial assembly performance relates to early mathematical skills. Child Development, 85(3), 1062-1076. https://doi.org/10.1111/cdev.12165

Voolpriit, S. (2016). J. A. Strebeleva metoodika (ülesanded 6-10) sobivus 3-aastaste Eesti laste arengu hindamiseks (magistritöö). Tartu: Tartu Ülikool.

Waismeyer, A. S., \& Jacobs, L. F. (2013). The emergence of flexible spatial strategies in young children. Developmental Psychology, 49(2), 232-242. https://doi.org/10.1037/a0028334

Wallerstedt, C., \& Pramling, N. (2012). Learning to play in a goal-directed practice. Early Years, 32(1), 5-15. https://doi.org/10.1080/09575146.2011.593028

Whitebread, D. (2017). Free play and children's mental health. The Lancet Child \& Adolescent Health, 1(3), 167-169. https://doi.org/10.1016/S2352-4642(17)30092-5 
Lisa 1. Sotsiaalsete oskuste küsimustiku faktoranalüüsi (Varimax normalized) tulemused

\begin{tabular}{|c|c|c|c|c|c|c|}
\hline Sotsiaalsete oskuste küsimustik & $\begin{array}{l}\text { Õpi- } \\
\text { edu }\end{array}$ & $\begin{array}{c}\text { Enese- } \\
\text { juhti- } \\
\text { mine }\end{array}$ & $\begin{array}{l}\text { Suhted } \\
\text { kaas- } \\
\text { lastega }\end{array}$ & $\begin{array}{l}\text { Osa- } \\
\text { vus }\end{array}$ & $\begin{array}{c}\text { Enese- } \\
\text { kesk- } \\
\text { sus }\end{array}$ & $\mathbf{R 2}$ \\
\hline jutustab hiljuti toimunud sündmustest & 0,71 & 0,03 & 0,17 & $-0,30$ & 0,17 & 0,62 \\
\hline püüab kaaslastega kokkuleppeid sõlmida & 0,69 & $-0,31$ & 0,24 & $-0,08$ & $-0,11$ & 0,66 \\
\hline püüab kurba inimest aidata ja lohutada & 0,67 & $-0,22$ & 0,28 & 0,02 & $-0,12$ & 0,57 \\
\hline $\begin{array}{l}\text { käitub vastavalt viisakusreeglitele (nt tänab } \\
\text { ja teretab) }\end{array}$ & 0,61 & $-0,12$ & 0,11 & $-0,06$ & $-0,16$ & 0,40 \\
\hline ootab heakskiitu, küsib „Kas nii on õige?“ & 0,59 & 0,08 & 0,08 & 0,01 & 0,09 & 0,34 \\
\hline jälgib, kas teised täidavad reegleid & 0,56 & 0,04 & 0,17 & $-0,21$ & 0,09 & 0,42 \\
\hline järgib mängureegleid & 0,56 & $-0,23$ & 0,07 & $-0,22$ & $-0,38$ & 0,57 \\
\hline alustab vestlust & 0,55 & 0,00 & 0,36 & $-0,36$ & 0,30 & 0,64 \\
\hline oskab teistega ära leppida & 0,54 & $-0,53$ & 0,13 & 0,07 & $-0,20$ & 0,61 \\
\hline $\begin{array}{l}\text { suudab sõnade abil arusaamatusi } \\
\text { lahendada }\end{array}$ & 0,54 & $-0,38$ & 0,12 & $-0,29$ & $-0,13$ & 0,55 \\
\hline kasutab mängides fantaasiat & 0,53 & 0,15 & 0,40 & $-0,22$ & $-0,11$ & 0,52 \\
\hline küsib täiskasvanult abi & 0,51 & $-0,07$ & 0,22 & $-0,06$ & 0,01 & 0,37 \\
\hline $\begin{array}{l}\text { on nõus oma asju lühikeseks ajaks teistele } \\
\text { andma }\end{array}$ & 0,44 & $-0,41$ & 0,21 & 0,09 & $-0,25$ & 0,44 \\
\hline rahuneb kiiresti, kui on pahaseks saanud & 0,12 & $-0,66$ & 0,26 & $-0,03$ & $-0,08$ & 0,42 \\
\hline nõustub tegema järeleandmisi & 0,19 & $-0,65$ & 0,14 & 0,01 & $-0,27$ & 0,50 \\
\hline $\begin{array}{l}\text { väljendab oma rahulolematust, et saada, } \\
\text { mida tahab }\end{array}$ & $-0,01$ & 0,65 & 0,19 & 0,14 & 0,36 & 0,59 \\
\hline püüab oma tahet maksma panna & 0,08 & 0,65 & 0,27 & $-0,02$ & 0,37 & 0,62 \\
\hline kaotab kergesti enesevalitsuse & 0,03 & 0,59 & $-0,10$ & 0,19 & 0,40 & 0,55 \\
\hline $\begin{array}{l}\text { väljendab oma tundeid sobimatus } \\
\text { olukorras }\end{array}$ & $-0,02$ & 0,59 & 0,04 & 0,21 & 0,37 & 0,50 \\
\hline käitub teiste suhtes agressiivselt & $-0,11$ & 0,52 & 0,09 & 0,21 & 0,42 & 0,51 \\
\hline lepib muutustega kergesti & 0,08 & $-0,52$ & 0,47 & $-0,08$ & $-0,04$ & 0,45 \\
\hline lepib kaotusega võistlusmängus & 0,18 & $-0,42$ & 0,32 & 0,20 & $-0,36$ & 0,46 \\
\hline lülitub kiiresti teiste mängu & 0,25 & $-0,11$ & 0,75 & $-0,25$ & 0,02 & 0,64 \\
\hline
\end{tabular}




\begin{tabular}{|c|c|c|c|c|c|c|}
\hline Sotsiaalsete oskuste küsimustik & $\begin{array}{l}\text { Õpi- } \\
\text { edu }\end{array}$ & $\begin{array}{l}\text { Enese- } \\
\text { juhti- } \\
\text { mine }\end{array}$ & $\begin{array}{l}\text { Suhted } \\
\text { kaas- } \\
\text { lastega }\end{array}$ & $\begin{array}{c}\text { Osa- } \\
\text { vus }\end{array}$ & $\begin{array}{c}\text { Enese- } \\
\text { kesk- } \\
\text { sus }\end{array}$ & $\mathbf{R} 2$ \\
\hline matkib kaaslasi & 0,09 & 0,00 & 0,65 & 0,14 & 0,01 & 0,31 \\
\hline naerab, kui teised nalja teevad & 0,34 & $-0,10$ & 0,61 & 0,01 & 0,04 & 0,47 \\
\hline naudib võistlusmänge & 0,24 & $-0,10$ & 0,60 & $-0,22$ & 0,04 & 0,47 \\
\hline teeb nalja, et teisi lõbustada & 0,40 & 0,02 & 0,60 & $-0,09$ & 0,13 & 0,57 \\
\hline algatab ise mänge, kuhu kutsub ka teisi & 0,43 & 0,05 & 0,54 & $-0,39$ & 0,18 & 0,68 \\
\hline hoiab rühmakaaslastest eemale & $-0,12$ & 0,04 & $-0,52$ & 0,29 & $-0,17$ & 0,36 \\
\hline $\begin{array}{l}\text { mängib lihtsamaid rollimänge, milles } \\
\text { kajastuvad igapäevased olukorrad ja } \\
\text { tegevused }\end{array}$ & 0,50 & 0,07 & 0,51 & $-0,23$ & $-0,15$ & 0,59 \\
\hline on eakaaslastega võrreldes kohmakas & $-0,21$ & 0,08 & $-0,27$ & 0,65 & 0,05 & 0,46 \\
\hline tema kõne on kõigile arusaadav & 0,43 & $-0,13$ & 0,10 & $-0,53$ & 0,08 & 0,46 \\
\hline $\begin{array}{l}\text { talle ei meeldi tegevused, mis nõuavad } \\
\text { püsivust ja vaimset pingutust }\end{array}$ & $-0,12$ & 0,08 & $-0,09$ & 0,51 & 0,40 & 0,32 \\
\hline rühmakaaslased ei taha teda mängu & $-0,10$ & 0,18 & $-0,23$ & 0,39 & 0,30 & 0,32 \\
\hline segab teiste jutule vahele & 0,01 & 0,22 & 0,05 & $-0,02$ & 0,81 & 0,65 \\
\hline räägib ise ega kuula, mida teine ütleb & 0,03 & 0,25 & 0,06 & 0,12 & 0,76 & 0,60 \\
\hline $\begin{array}{l}\text { vastab enne, kui küsimus on lõpuni } \\
\text { esitatud }\end{array}$ & 0,13 & 0,18 & 0,10 & $-0,14$ & 0,71 & 0,49 \\
\hline hindab oma oskusi üle & 0,14 & 0,24 & 0,00 & 0,04 & 0,62 & 0,40 \\
\hline ootab oma järjekorda & 0,38 & $-0,32$ & 0,01 & 0,10 & $-0,60$ & 0,57 \\
\hline võtab luba küsimata teiste laste asju & $-0,23$ & 0,31 & 0,15 & 0,12 & 0,54 & 0,46 \\
\hline justkui ei kuule, mida tal tuleb teha & $-0,17$ & 0,15 & 0,04 & 0,39 & 0,53 & 0,41 \\
\hline Expl. Var & 5,86 & 4,47 & 4,24 & 2,42 & 4,84 & \\
\hline Prp. Totl & 0,14 & 0,11 & 0,10 & 0,06 & 0,12 & \\
\hline
\end{tabular}

Märkused. Tumedas kirjas on esile tõstetud faktorlaadungid, mille alusel rühmitati väited faktoritesse; kaldkirjas on esitatud negatiivse laadungiga väited. Expl. Var - komponendi hajuvus; Prp. Totl - osa kogu seletatud hajuvusest. 
Lisa 2. Sotsiaalsete oskuste küsimustiku faktoranalüüsi kirjeldavad näitajad

\begin{tabular}{|l|c|c|c|c|c|}
\hline Faktor & $\begin{array}{c}\text { Cron- } \\
\text { bachi } \alpha\end{array}$ & $\begin{array}{c}\text { Oma- } \\
\text { väärtus }\end{array}$ & $\begin{array}{c}\text { Protsent } \\
\text { kogu varia- } \\
\text { tiivsusest }\end{array}$ & $\begin{array}{c}\text { Kumula- } \\
\text { tiivne oma- } \\
\text { väärtus }\end{array}$ & $\begin{array}{c}\text { Kumulativne } \\
\text { protsent kogu } \\
\text { variatiivsusest }\end{array}$ \\
\hline Õpiedu & 0,88 & 10,43 & 25,43 & 10,43 & 25,43 \\
\hline Enesejuhtimine & 0,85 & 6,74 & 16,44 & 17,17 & 41,87 \\
\hline Suhted kaaslastega & 0,86 & 1,79 & 4,37 & 18,96 & 46,23 \\
\hline Osavus & 0,60 & 1,61 & 3,93 & 20,57 & 50,16 \\
\hline Enesekesksus & 0,85 & 1,26 & 3,07 & 21,83 & 53,24 \\
\hline
\end{tabular}




\title{
Level of transferable skills according to three assessment tools in three and four-year-old Estonian children
}

\author{
Pille Häidkind $^{\text {a1 }}$, Astra Schults ${ }^{\text {ab }}$, Kaili Palts ${ }^{\text {ac }}$ \\ ${ }^{a}$ Institute of Education, University of Tartu \\ ${ }^{b}$ Institute of Psychology, University of Tartu \\ ${ }^{c}$ Haapsalu Neurological Rehabilitation Centre
}

\section{Summary}

Estonian kindergarten teachers have a responsibility to assess the personal development of children in every school year and to give an overview of their progress to the children's parents. Teachers rely on the kindergarten's curriculum to assess the development and level of transferable skills of three and fouryear-old children. Curricula are developed separately in each of the kindergartens and teachers themselves are taking part in the development process. To do so, they can use some reference books that have been published by the government. They can also, use the official preschool age state curriculum, where the level of transferable skills is specified for the six and seven-year-old children. In Estonia, the research about the actual level of transferable skills at earlier ages has been sparse and our aim is to fill a part of this gap.

Applied research to collect data about Estonian preschool children's knowledge and transferable skills was led by the University of Tartu researchers between 2014 and 2016. We describe here one part of the data collection and present results from that part of the research regarding transferable skills of three and four-year-old children. To collect data about social and reflexive skills we used the Social Skills Questionnaire for the teachers. The Social Skills Questionnaire is developed in the University of Tartu and teachers can use it to evaluate how often they have seen children to use social and reflexive skills. We collected data from 450 children by using the Social Skills Questionnaire. To collect data about cognitive and learning skills we used the Strebeleva method and collected data from 262 children. To collect data about cognitive, motor, and learning skills we used Psychoeducational Profile 3rd edition for 127 children. Data using Strebeleva method and Psychoeducational Profile were collected via testing each participant individually. Different children participated

Institute of Education, University of Tartu, Salme 1a, 50103 Tartu, Estonia; pille.haidkind@ut.ee 
in data collection with different assessment tools. All the children attended regular kindergartens, they were healthy, they did not need any special needs support, and had Estonian as their native language according to their parents and teachers. The participants were recruited from all over Estonia.

The results showed that social and reflexive skills listed in the Social Skills Questionnaire can be divided into five factors. The factors were the following: academic, self-management, peer-relations, motor, and assertion. We did not find significant age differences or systematic gender differences in the teachers' evaluations of children's social and reflexive skills. At the same time their selfmanagement, motor, and assertion skills had yet to be developed and none of these specific skills appeared to be in regular use. Teachers evaluated the frequency of three and four-year-olds to talk about recent events, to be polite, to follow the game rules, to start conversations, to be able to make up with peers, and to ask an adult for assistance to be high. Children were also evaluated frequently to laugh when others made jokes and to play role games. Teachers evaluated the frequency of three and four-year-olds to keep their distance from peers to be rare. At the same time children's self-management, motor, and assertion skills were evaluated not to be in a regular use.

According to the results from the Strebeleva method we found that three and four-year-old children are able to name the objects they see in the pictures but are unable to describe or discuss what is presented in the picture without additional help from an adult. We also found that Estonian children had difficulty assembling pictures if the parts had straight edges, compared to assembling pictures from the pieces that had particular shaped edges.

According to the Psychoeducational Profile 3rd edition the motor skills of the three and four-year-old children are well developed. They are able to handle balls in multiple ways and use scissors, also the coordination between the leading hand, leg, and eye has been developed. They are able to draw simple geometrical shapes such as circles and lines. They also imitate movements, two-part actions, and verbally presented sentences that contain three to four words. Transferable skills are best observed during play behaviors. According to the teachers three and four-year-old children like to act together with their peers, they enjoy role play that includes everyday activities, and are able to follow game rules. The children are also able to use everyday items in their games and imitate how these items are used by people during their daily activities.

We compared the descriptions of transferable skills given in the reference books and kindergarten curricula with the results from our study. We found that some of the expectations described in these materials were consistent with the skill levels that we found. For example, three and four-year-old children are described as talkative and have the ability to start conversations easily. At 
the same time, the guideline materials included some learning outcomes that we found to be beyond children's comprehension. For example, children are expected to compare squares and rectangles but these terms are not in their vocabulary, and they are unable to imitate drawings of those two shapes. The main problem with the materials is that they are presented in a general way that makes it difficult for a teacher to design transferable skills assessment. In addition to this, the materials should be reviewed in the future when research has provided more specific evidence about the transferable skills development.

Our main conclusion stresses the importance of knowing what is to be expected from three and four-year-old children regarding their transferable skills. When teachers know what to expect, they are able to concentrate on the skills that need developing. Also, it is necessary to keep in mind that children need constant encouragement in order to practice the tasks they need developing. If this fails to motivate them they need verbal instruction. When this is not helpful enough, the next step would be to provide children with a model and actions that they can imitate. It should be kept in mind that in order to develop new skills children need teachers to take the lead and to use well planned teaching activities.

Keywords: transferable skills in kindergarten, social and reflexive skills, cognitive skills, learning skills, play skills, three and four-year-old Estonian children 